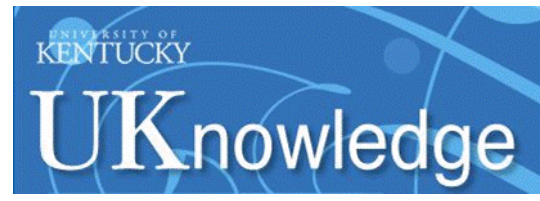

University of Kentucky

UKnowledge

\title{
The Consumer Protection Ecosystem: Law, Norms, and Technology
}

Christopher G. Bradley

University of Kentucky College of Law, cgbradley@uky.edu

Follow this and additional works at: https://uknowledge.uky.edu/law_facpub

Part of the Consumer Protection Law Commons

Right click to open a feedback form in a new tab to let us know how this document benefits you.

\section{Repository Citation}

Bradley, Christopher G., "The Consumer Protection Ecosystem: Law, Norms, and Technology" (2020). Law Faculty Scholarly Articles. 646.

https://uknowledge.uky.edu/law_facpub/646

This Article is brought to you for free and open access by the Law Faculty Publications at UKnowledge. It has been accepted for inclusion in Law Faculty Scholarly Articles by an authorized administrator of UKnowledge. For more information, please contact UKnowledge@lsv.uky.edu. 


\section{The Consumer Protection Ecosystem: Law, Norms, and Technology}

\section{Notes/Citation Information}

Christopher G. Bradley, The Consumer Protection Ecosystem: Law, Norms, and Technology, 97(1) Denv. L. Rev. 35 (2020) 


\title{
The Consumer Protection Ecosystem: LAw, Norms, AND TECHNOLOGY
}

\author{
CHRISTOPHER G. BRADLEY ${ }^{\dagger}$
}

\begin{abstract}
In recent years, the tools consumers use to buy and borrow have changed radically. New technologies for advertising, contracting, and transacting have proliferated, and so have fierce policy debates on issues such as identity theft and online privacy; arbitration clauses and class action lawsuits; and Americans' accumulation of debt and the unsavory practices sometimes used by collectors of it. Facing these realities, scholars, policymakers, and advocates have devoted increasing energy to this area of law. Despite its prominence, confusion persists regarding what consumer protection really is or does. Though much discussed, it remains undertheorized. In particular, analysis of consumer law and policy has not sufficiently taken account of the implications of social and technological change.

This Article constructs a new model of the consumer protection ecosystem by contextualizing purely legal constraints amid the other realities of commercial relationships. Drawing on scholarship in the areas of technology, social change, and law, the model lays out three basic types of constraints on the activities of participants in consumer commercial transactions: legal, technical, and social. This model provides a basis for exploring how those constraints interact and shape behavior.

The model has significant ramifications for scholars, policymakers, and advocates. It underscores why the area of consumer commerce defies one-size-fits-all solutions: good policies require not only consideration of consumers, merchants, and the commercial relationships they pursue, but of the dynamic social and technological contexts of those relationships. For instance, when technology opens unexpected new areas of feasible conduct, both law and social norms may lag behind in their ability to constrain its socially undesirable aspects. Focused, public deliberation and increased regulatory attention may be merited at least until social norms have developed to define the acceptable contours of such conduct. This

$\dagger$ Assistant Professor of Law, University of Kentucky College of Law; A.B., Princeton; M.Phil., D.Phil., Oxford; J.D., LL.M., NYU. Sincere thanks to Zack Bray, Matthew Bruckner, Stephen Calkins, Pamela Foohey, Michael Livermore, Amy Schmitz, Harry Surden, Martin Sybblis, Kate Tokeley, Rory Van Loo, and Lauren Willis, as well as participants at workshops at the University of Kentucky, at Law \& Society 2018, at Teaching Consumer Law 2018, at South Eastern Assoc. of Law Schools 2018, at Junior Scholars Virtual Colloquium 2017, and at Central States Law Schools 2017. I am grateful for the research assistance of Kaylie Raber and summer research funding from the University of Kentucky College of Law.
\end{abstract}


Article provides a more refined and inclusive framework for future research and debate.

\section{TABLE OF CONTENTS}

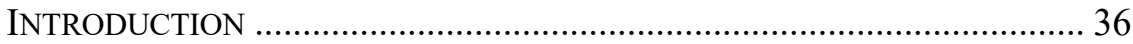

I. A MODEL OF THE CONSUMER PROTECTION ECOSYSTEM ................... 42

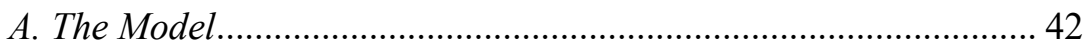

1. Legal Constraints............................................................. 43

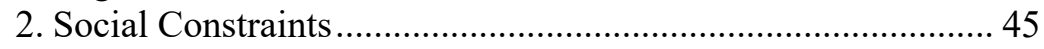

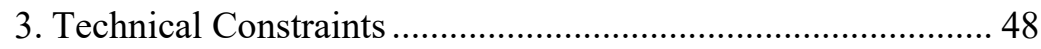

B. Reading the Model ................................................................ 50

C. A Taxonomy of Consumer Commercial Actions and

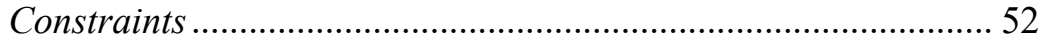

D. Why a Model of "Consumer Protection"? ................................... 60

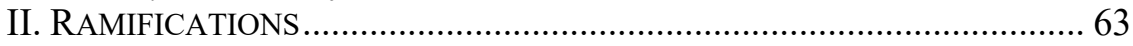

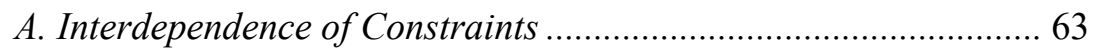

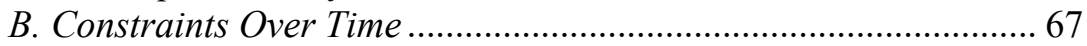

C. Implications of Technological Change for Consumer Policy....... 70

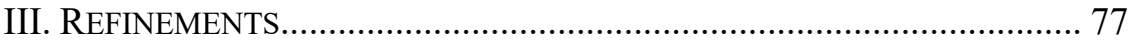

A. Varieties of Consumers, Merchants, and

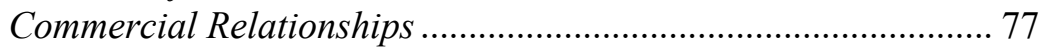

B. Consumer Self-Defense and Learning ........................................ 80

C. Systemic Risk, Discrimination, Innovation, and

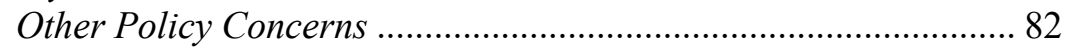

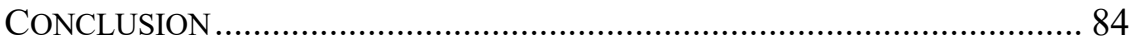

\section{INTRODUCTION}

As consumers, we all buy and borrow. For example, we buy everyday goods and services from some merchants. And, we borrow money for long-term investment, short-term liquidity, or simple convenience from others. Due primarily to technological change, the tools with which we buy have changed substantially in the past decade - and certainly in the half-century or more since most laws regulating consumer transactions came into force.

Few areas of public policy have drawn fiercer debate in recent years than consumer protection. In part, these debates reflect the fact that we are all consumers, affected by this area of policy every day of our lives. In addition, vast sums of money are at stake. Many of the largest companies in the world appear on the other side of consumer transactions, selling us products, lending us money, or collecting our increasingly valuable personal data in exchange for online services. ${ }^{1}$ Most of all, technological de-

1. See, e.g., Nancy Moran, Apple Falls to Fourth-Biggest U.S. Company by Market Value, BlOOMBERG (Jan. 3, 2019, 2:11 PM), https://www.bloomberg.com/news/articles/2019-01-03/apple- 
velopments have provoked upheaval in this area; the pervasiveness of mobile technology and online commerce has unsettled social norms and rendered regulatory regimes obsolete. ${ }^{2}$ Consumers may feel empowered and relieved at easier transacting ${ }^{3}$ - but at the same time feel troubled and victimized by the complex, take-them-or-leave-them terms imposed by online intermediaries that have so quickly become ubiquitous and inescapable. $^{4}$

No wonder, then, that consumer protection has provoked fierce policy debate on issues such as identity theft, ${ }^{5}$ online privacy, ${ }^{6}$ arbitration clauses, ${ }^{7}$ Americans' accumulation of debt, and the unsavory practices sometimes used by would-be collectors of that debt. ${ }^{8}$ In response to these debates and developments, scholars, policymakers, and advocates devote increasing energy to this area of law.

Despite this attention, confusion persists regarding what consumer protection really is or does. The realities of social norms and technological change have not been fully integrated into legal analyses of consumer transactions. Drawing on scholarship in the areas of technology, social norms, and law, this Article constructs a new model of the consumer protection ecosystem ${ }^{9}$ by contextualizing legal constraints within the lived realities of commercial relationships. This realist-inflected model situates

is-now-fourth-biggest-u-s-company-by-market-value-chart (noting that Alphabet, Google's parent company, Apple, Microsoft, and Amazon were the top four most valuable U.S. companies by market capitalization).

2. See, e.g., Austan Goolsbee, How Consumers Can Resist Companies' Market Power, N.Y. TIMES (July 20, 2018), www.nytimes.com/2018/07/20/business/how-consumers-can-resist-companies-market-power.html.

3. See, e.g., Christopher G. Bradley, FinTech's Double Edges, 93 CHI.-Kent L. REV. 61, 6380 (2018) (describing financial technologies that have lowered transaction costs, while potentially imposing some new costs).

4. See, e.g., Farhad Manjoo, Tech's Frightful Five: They've Got Us, N.Y. TIMES (May 10, 2017), https://www.nytimes.com/2017/05/10/technology/techs-frightful-five-theyve-got-us.html.

5. See, e.g., Adam Janofsky, One Year After Equifax Breach: Criminal Charges, New State Laws and Lost Chances, WALL ST. J. (Sept. 7, 2018, 11:34 AM), https:/www.wsj.com/articles/oneyear-after-equifax-breach-criminal-charges-new-state-laws-and-lost-chances-1536334479 (describing regulatory efforts in the aftermath of theft of almost 148 million individuals' personal information by major credit rating agency).

6. See, e.g., Daisuke Wakabayashi, California Passes Sweeping Law to Protect Online Privacy, N.Y. TIMES (June 28, 2018), www.nytimes.com/2018/06/28/technology/california-online-privacy-law.html.

7. See, e.g., DIRECTV, Inc. v. Imburgia, 136 S. Ct. 463, 465-66 (2015) (upholding class action waiver in arbitration agreement).

8. See, e.g., Chris Arnold, Who Snatched My Car? Wells Fargo Did, NPR (Aug. 2, 2017, 5:47 PM), http://www.npr.org/2017/08/02/541182948/who-snatched-my-car-wells-fargo-did (noting that Wells Fargo enrolled approximately 490,000 auto loan customers for unneeded and duplicative auto insurance, leading to many defaults and repossessions of cars); Stacy Cowley, Debt Collectors' Abuses Prompt Consumer Agency to Propose New Rules, N.Y. TimeS (July 28, 2016), www.nytimes.com/2016/07/28/business/dealbook/debt-collectors-abuses-prompt-consumer-agency-to-propose-new-rules.html.

9. Ecosystem can be defined as "the complex of a community of organisms and its environment functioning as an ecological unit.” Ecosystem, MERRIAM-WEBSTER, https://www.merriam-webster.com/dictionary/ecosystem (last visited Oct. 11, 2019). In this context, as the model shows, it includes the constraints operating on both merchants and consumers who might wish to engage in a particular action or behavior. See also infra Part II.C (discussing rationale for the model). 
consumer law amid other factors affecting those engaging in commerce. The model serves as a theoretical basis for an integrated and nuanced consideration of the different parts of what has been known as "consumer protection" (itself a problematic term ${ }^{10}$ ). The model builds on the realist intuitions that motivate much advocacy work both for and against current laws and policies, and considers the distinct types of constraints relevant to the regulation of consumer commercial relationships.

This Article proceeds as follows. Part II explains the premises of the model and lays out its basic features. This model relies on three different types of constraints on consumer commercial transactions: legal, technical, and social. "Legal constraints" are produced by laws, the remedies available for their breach, and the capacity of the institutions charged with enforcing them. ${ }^{11}$ Actions not deterred by adequate legal constraints are "legally feasible" actions. "Technical constraints" are those that are impossible due to the current state of technology, or possible but too expensive to be feasibly implemented. ${ }^{12}$ Actions not subject to such constraints are "technically feasible." "Social constraints" depend on social attitudes; they prohibit actions that cannot be successfully hidden and that, when publicly known, will draw condemnation and have high reputational consequences. ${ }^{13}$ Actions that can either be hidden or would not bring social opprobrium if discovered are "socially feasible."

Under this model, the set of "permitted actions" in consumer commercial relationships consists of everything not effectively barred by legal, technical, or social constraints. It is from this set of permitted actions that consumers and merchants choose when they engage in commerce. ${ }^{14}$ Actions outside the set of permitted actions are, in effect, not possible; consumers are "protected" from such actions, even if they would otherwise prefer them.

The model examines the exogenous factors that constrain parties from engaging in behavior they would otherwise prefer to take. The model's analytical framework looks to the experienced constraints on the participants in relationships rather than merely legal constraints. In the same way social scientists have demonstrated that "order without law" can arise by virtue of complex social forces and technologists have argued that "code is law" because software code regulates software users' conduct,

10. See infra note 93 and accompanying text.

11. See infra Part II.A.1. For a high-level summary of the consumer law regime, see JOHN A. SPANOGLE ET AL., CONSUMER LAW: CASES AND MATERIAls 6-8 (4th ed. 2013).

12. See infra Part II.A.3.

13. See infra Part II.A.2.

14. The model adopts the realist, "law-in-action," orientation of scholars such as Stuart Macauley. See generally Stewart Macaulay \& Elizabeth Mertz, New Legal Realism and the Empirical Turn in Law, in 1 THE NEW LEGAL REALISM: TRANSLATING LAW-AND-SOCIETY FOR TODAY'S LEGAL PRACTICE (Elizabeth Mertz et al. eds., 2016). The core commitment of such an approach is to develop policy based on an empirical, social science-influenced, practical consideration of the nature and effect of legal tools such as contracts. 
this Article identifies nonlegal constraints that "regulate" the conduct of those engaged in consumer transactions. ${ }^{15}$

The analogy of legal constraints to social constraints, or to code and other technologically based constraints, is not perfect. Actors may feel and behave differently in the face of social versus legal constraints - some will be more constrained by one than the other. ${ }^{16}$ Still, each type of constraint can effectively deter an action, any time, for any actor. For the purposes of policy analysis, that deterrence is important regardless of how it is obtained.

This model does not rely on any particular views on, or justifications for, the regulation of consumer commercial relationships. Indeed, the model could be used to argue that nonlegal tools provide sufficient constraints, and market actors should be uninhibited by law. Alternatively, the model could serve as the basis for an argument that more radical legal intervention is required - particularly in times of disruptive technological advances that render existing regulatory regimes outdated. Either way, this model provides a better tool for developing tailored policy approaches and for considering the type and intensity of constraint most appropriate under given circumstances. ${ }^{17}$ Thus, while the model itself is descriptive, it has normative implications for policy in the realm of consumer commercial relationships.

Debates about consumer law and policy tend to turn on whether, with respect to a particular form of behavior, "the market" is working or will work properly. If not, then legal intervention is thought to be necessary; if

15. My model is deeply influenced by many of the influential observations made by Lawrence Lessig, both in his essay The New Chicago School, 27 J. LEG. STUDS. 661, 661-63 (1998), and in his seminal work CODE AND OTHER LAWS OF CYBERSPACE (1999). Even more directly, I have drawn from the excellent reworking of these ideas in the intellectual property arena by Harry Surden. See Harry Surden, Technological Cost as Law in Intellectual Property, 27 HARV. J. L. \& TECH. 135, 136 43 (2013). The work of Robert Ellickson is of course fundamental as well to any work on law and social norms and has influenced this work deeply. See ROBERT C. ELLICKSON, ORDER WITHOUT LAW: HOW NeIGHBORS SETTLE Disputes 126, 127 (1994).

16. It is widely recognized that there are salient differences in the way law functions as opposed to other forms of limitation, different forms of responses to legal constraints as opposed to other forms of constraint (including code, technological cost, reputational sanction, etc.). James Grimmelman, Note, Regulation by Software, 114 YALE L.J. 1719, 1721-24 (2005) (outlining different "modalities" of regulation, including law, code, architecture, etc.). "Legal consciousness" and "legal culture" are two ways that "law and society" scholars have thought about the distinctiveness of law and legal force as opposed to other forms of power and control, both from the perspective of the regulator and the regulated. See, e.g., Sally Engle Merry, Legal Pluralism, 22 L. \& SoC’Y REV. 869, 884, 888 (1988) (discussing analogies and distinctions between law and other forms of social "discipline"); Laura Beth Nielsen, Situating Legal Consciousness: Experiences and Attitudes of Ordinary Citizens About Law and Street Harassment, 34 L. \& SoC'Y REV. 1055, 1055-56 (2008) (discussing how certain groups perceive the role of law in their affairs); Austin Sarat \& William L. F. Felstiner, Lawyers and Legal Consciousness: Law Talk in the Divorce Lawyer's Office, 98 Yale L.J. 1663, 1663-64 (1989) (providing seminal discussion of literature on "legal consciousness").

17. Thus, as discussed further below, see infra note 93 and accompanying text, the model itself should not be read as an endorsement of the rather loaded, traditional concept of "consumer protection," which implicitly and narrowly conceives of the policy goal as "protecting" consumers from merchants. The term consumer protection is preserved only because "consumer law" is too narrow, as it focuses solely on legal constraints; the more accurate and neutral "policies affecting consumer commercial relationships" is too cumbersome. 
so, then the market should be trusted and left alone. Advocates for regulation focus on particular, perceived market failures and call for intrusive legal solutions. Opponents of regulation stress the general reliability of the market's resource allocations as well as the expenses of regulation. ${ }^{18}$ Debates between these competing normative perspectives are important, but all of these debates rely on underlying theories of consumer and merchant behavior that need more examination. This Article implicitly urges that the dichotomy of "law versus markets" is unsatisfactory. The scholarship on consumer law and commerce lacks a general framework for conceiving how laws and markets alike interact with other factors that influence the consumer commerce ecosystem over time - in particular, social and technical factors. This Article begins to fill the gaps in the existing literature by proposing that we include a pragmatically driven emphasis on the functional constraints on merchants and consumers in their commercial ecosystem. The model at the heart of this Article considers the constraintssocial, technical, and legal - that override what would otherwise be the market preferences of the consumer and merchant engaging in a consumer transaction. This perspective is novel and important. It may be implicit in some existing accounts, but a goal of this Article is to make explicit what has been implicit. The theoretical foundation of consumer protection affects policy making, and only when laid out explicitly in detail can the foundation be critiqued and refined.

Social and technical factors are not entirely separate from either law or markets (nor are law and markets analytically distinct phenomena). Rather, these factors are influenced by one another. It is true that social and technological factors can be, and are, considered "costs" to participants in transactions and analyzed as part of the market. So can the costs imposed by laws. Many valuable scholarly works implicitly take that approach. ${ }^{19}$ But that broad conception of "market" can be both underinclusive and overinclusive. It is overinclusive because it lumps together so many different types of costs, short-term and long-term, reputational and monetary; it is underinclusive because it fails to give particularized attention to the innovations and the social changes that actually determine social and technological costs. Under existing legal as well as economic analyses, social

18. See, e.g., Christopher L. Peterson, TAMING THE Sharks: TOWARDS A CuRE FOR THE HIGH-COST CREDIT MARKET 43-44 (2004) (summarizing arguments of opponents of aggressive consumer protection laws). In addition to policy arguments, of course both sides rely on the forms of raw power available to them: largely behind-the-scenes lobbying and political influence on the part of the opponents of regulation, and largely social organizing and the publicizing of particular stories of abuse on the part of consumer advocates. These political strategies are beyond the scope of this model, although they are relevant aspects of how both legality and social acceptability is determined for particular practices.

19. See, e.g., Oren Bar-Gill, Seduction by Contract: Law, Economics, And PSYCHOLOGY IN CONSUMER MARKETS 26, 101, 191, 233, 237 (2012) (including a section on "market solutions" within each chapter); Yonathan A. Arbel, Reputation Failure: The Limits of Market Discipline in Consumer Markets, WAKE FOREST L. REV. (forthcoming 2019) (draft available at https://papers.ssrn.com/sol3/papers.cfm?abstract_id=3239995) (providing a useful survey and analysis of literature on "market failures" focused on reputation). 
and technological factors remain underappreciated aspects of the consumer protection ecosystem. There is a value in considering these factors distinctly, rather than merely as lumped into an oversized and imprecise category of "market dynamics," even if these factors are eventually reincorporated into an analysis that relies on economic methodologies (as most policy analyses ultimately do).

Part III discusses some ramifications of the consumer protection model constructed in this Article. This model provides the basis for an argument that more attention should be paid to (a) the interdependence of legal and other forms of constraints on consumer commercial interactions, and (b) the assessment of changes over time. These two aspects are linked. Changes in one type of constraint - for instance, the development of a new area of technology, or a change in legal regime-will affect the others. Changes in technology may affect the social acceptability of an activity ${ }^{20}$ or the social acceptability of conduct may affect its legal permissibility. Or, less directly, changes in one type of constraint may expand or contract the set of permitted actions, which over time may add pressure to ease, or to tighten, other types of constraints. Policymakers should be aware of this interdependence as they consider regulatory strategies. ${ }^{21}$ In addition, the propensity for the balance of different constraints to change over time should be considered more consistently and systematically. Perhaps most importantly, when technology opens unexpected new areas of feasible conduct, both law and social norms may lag behind in their ability to constrain its socially undesirable aspects. Focused, public deliberation and increased regulatory attention may be merited-at least until social norms have developed to define the acceptable contours of such conduct.

20. For example, technology seems to have shaped expectations of privacy, expectations concerning the degree of formality required to complete a commercial transaction, and expectations concerning dispute resolution. See, e.g., Amy J. Schmitz, Remedy Realities in Business-to-Consumer Contracting, 58 ARIZ. L. REV. 213, 248 (2016) ("PayPal's and eBay's [Online Dispute Resolution] programs have garnered customer support because these programs allow customers to efficiently obtain remedies without the costs and hassles of traditional claims processes."); Aaron Smith \& Monica Anderson, Online Shopping and E-Commerce, PEW RESEARCH CENTER (Dec. 29, 2016), https://www.pewinternet.org/2016/12/19/online-shopping-and-e-commerce/ ("[T]oday nearly as many Americans have made purchases directly through social media platforms as had engaged in any type of online purchasing behavior 16 years ago.").

21. For instance, where effective constraints are already in place due to social forces or practical factors, regulatory action may be less necessary. This suggestion implicates a rich literature on the respective capacities of state versus market and other social forces. For instance, law and development scholars have explored the circumstances under which state actors or private actors might be best positioned to address a policy problem, and the circumstances in which particular forms or coordination might be required. See, e.g., David Trubek \& Alvaro Santos, Introduction: The Third Moment in Law and Development Theory and the Emergence of a New Critical Practice, in THE NEW LAW AND ECONOMic DeVElopment: A Critical APPRAisal 1 (David Trubek \& Alvaro Santos eds., 2006) (discussing the historical academic literature on the dynamic of states versus markets in development); Pranab Bardhan, State Development: The Need for a Reappraisal of the Current Literature, $54 \mathrm{~J}$. ECON. LiT. 862, 862 (2016) (surveying literature on the role of state versus other actors in development). I am grateful to Martin Sybblis for helping me see the connection between this Article's model and that literature. 
Part IV considers potential objections to this model and addresses several ways in which it could be refined in future research. In the generalized form presented here, the model lumps together constraints that may operate differently on various sorts of consumers, merchants, or transactions. An online advance procured on a mobile device through an app that could be accessed by children may (or should) be subject to different constraints than a traditional loan applied for in-person by adults. ${ }^{22}$ Further work should refine and customize this model to fit each individual situation. It should be revisited to accommodate each point in time, each type of merchant or consumer, and each type of commercial transaction or relationship.

This aspect of the model underscores a broader principle concerning the law and policy of consumer commercial relationships, which is too often forgotten or neglected: there are unlikely to be one-size-fits-all analyses or conclusions in this area. To the contrary, to develop appropriate policies we must pursue refined and layered consideration of consumers, the merchants, and the commercial relationships they seek. Additionally, we must consider the changes in the social, technical, and legal contexts of those relationships. Accordingly, this Article endeavors to provide a framework for considering the comprehensive sociolegal and technological context in which consumers and merchants transact.

\section{A MODEL OF THE CONSUMER PROTECTION ECOSYSTEM}

\section{A. The Model}

This Part lays out the basic premises and structure of the consumer protection ecosystem model. This model emphasizes that consumer protection, as experienced by participants in consumer commerce, has a scope that is delineated not just by governing law but also by the actual feasibility of particular actions ${ }^{23}$ - both as a technical matter (i.e., the tools to engage in the transaction are reasonably available ${ }^{24}$ ) and as a social matter (i.e., the activities are socially acceptable). As discussed further below, this Article does not argue or analyze whether or not participants should

22. The problem of children engaging in unauthorized financial transactions for a caregiver's phone has already caused problems for major technology companies. See, e.g., Edward Wyatt \& Brian X. Chen, Apple to Refund App Store Purchases Made Without Parental Consent, N.Y. TimES (Jan. 15, 2014), https://www.nytimes.com/2014/01/16/technology/government-and-apple-settle-childrensapp-purchase-inquiry.html.

23. For the concept of an "effective scope" of laws, see Surden, supra note 15 which, distinguishes effective scope from positive scope and provides a theoretical framework. Professor Surden explored similar ideas in his prior work, Structural Rights in Privacy, 60 SMU L. REV. 1605, 160510 (2007).

24. For a similarly broad definition of "technology," see, e.g., Kevin E. Davis, Contracts as Technology, 88 N.Y.U. L. REV. 83, 85 (2013) ("[T] he term 'technology' can ... be defined more broadly as 'useful knowledge about how to produce things at low cost." (quoting WiLliam EASTERLY, THE Elusive Quest FOR GROWTH: ECONOMISTS' ADVENTURES AND MisAdVENTURES IN THE TROPICS 150 (2001)). As explained further below in Subsection 3, my definition of "technically feasible" actions includes the cost of the relevant tools or actions. 
or should not be barred from particular activities. There is a range of reasonable views on such questions, and this model does not force a choice because it can accommodate that entire range. This model is limited to the descriptive issues of what consumer protection is, what is actually protected, and what happens to that protection when the world changes.

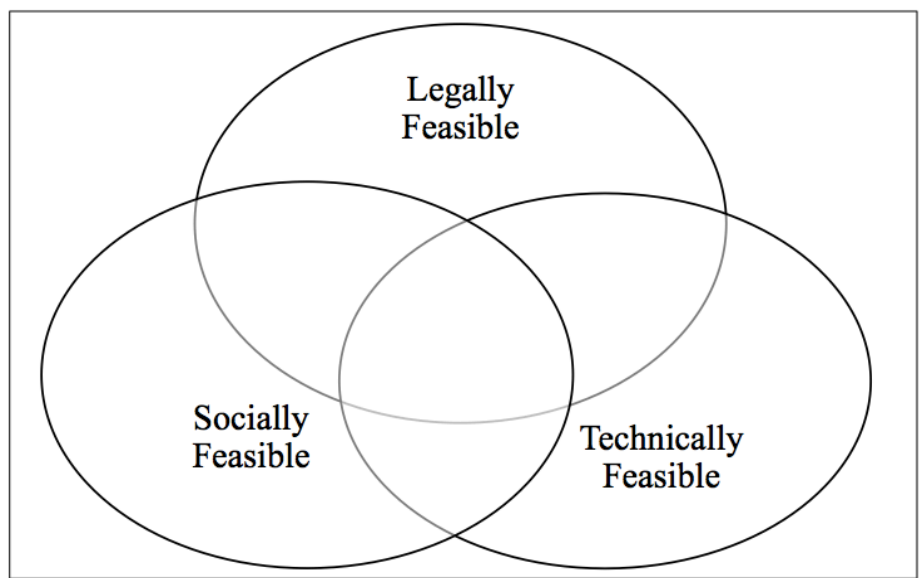

Figure 1.

The model may be laid out as follows. Start with the universe of all possible actions that participants might take regarding a consumer commercial relationship. These actions include: (1) the communications between the parties in the process of advertising and negotiation, including disclosures, conditions, and warranties; (2) the actions taken entering into the transaction, including indications of consent and agreement; (3) the actions taken to comply with or enforce the terms of the transaction, including payment, delivery, repossession, foreclosure, or other means of pursuing relief upon default; and (4) the various ancillary actions such as the later commercial use of information gained in an earlier interaction (e.g., sale of customer information to a data broker). These are the actions under consideration by the model. The entire inside area of the perimeter rectangle of Figure 1 represents the universe of such actions. ${ }^{25}$

\section{Legal Constraints}

First, consider the set of such actions that are legally feasible (as labeled in Figure 1 above). Legal feasibility refers to actions that fall afoul of enforced legal prohibitions and bring penalties sufficient to deter parties from engaging in them. The boundaries of this area represent the existing body of legal constraints on actions that can be taken in consumer commercial relationships.

25. The size of the respective areas of the Venn diagram are not drawn to any scale. Future research could estimate and render some of the areas proportionately to one another, though such estimates would remain somewhat speculative, as explained in the rest of this Part of the Article. In any case, the insights of the model laid out in this Article can be understood from the model as depicted here. 
Legal constraints can be conceived broadly, including ex ante regulation as well as ex post enforcement actions by private litigants and public officials. Legal constraints include a large body of law and regulation at the federal and state levels. Relevant laws include not just substantive liability rules but also rules concerning jurisdiction, standing, remedies, and so on, which are integral parts of the legal regime in place at a given time. Legal constraints in this model also include the institutions-agencies, courts, lawyers, and others ${ }^{26}$ - that are responsible for the determination, evaluation, or resolution of legal rights and disputes. Note that while this model is one of "consumer protection," which implies protection from a consumer's commercial counterparties, merchants are not the only participants subject to restriction. Consumers are barred from taking certain actions, too, out of concern for merchants or, paternalistically, to protect consumers from themselves. ${ }^{27}$

For an action to be legally feasible, it must either (1) not be prohibited by law (defined broadly as any law or regulation, at any jurisdictional level, to which the party is subject); or (2) not be subject to effective enforcement, whether because violations are difficult to detect, because penalties are insufficiently likely to be imposed, or because the penalties are insufficiently severe, when imposed, to actually deter the prohibited conduct.

Prohibition is not enough on its own. A party may be prohibited from taking certain otherwise-profitable actions under governing law, but if prohibitions are not enforced, or the sanctions are low, the rules are unlikely to deter the action. For example, scholars have noted that banks foreclosing on homeowners who are in default frequently retain contractors who have allegedly committed a wide variety of illegal acts without facing meaningful sanction. ${ }^{28}$ Such prohibited, but undeterred, "bad behavior" is a primary focus of consumer policy analysis. Fierce debates revolve around the availability of statutory penalties, attorney's fees, class actions,

26. For instance, state and federal lawmakers; regulators such as the Federal Trade Commission, Consumer Finance Protection Bureau, state attorneys general; public interest organizations; the private bar; and judges. Consumer law is effectively surveyed in RICHARD M. ALDERMAN \& DEE PRIDGEN, CONSUMER PROTECTION AND THE LAW (2019).

27. Much of consumer law and policy is driven by paternalistic concern for consumers misjudging situations - making decisions adversely affecting their own welfare in ways thought inefficient or unjust. See, e.g., Peterson, supra note 18, at 160-98; Kathleen C. Engel \& Patricia A. McCoy, A Tale of Three Markets: The Law and Economics of Predatory Lending, 80 TEX. L. REV. 1255, 1347 (2002); Lauren E. Willis, When Nudges Fail: Slippery Defaults, 80 U. CHI. L. REV. 1155, 1316 (2013) ("The metagoals of consumer law include consumer decisional autonomy in the marketplace; market transactions that optimize consumer welfare; and intraconsumer fairness, particularly for disadvantaged consumers." (citations omitted)). Of course, as noted elsewhere, there are other justifications, including reducing externalities imposed on society as a result of particular transactions, and correcting perceived distributive problems. See, e.g., BAR-GILL, supra note 19, at 4, 26; PETERSON, supra note 18 at 200-30 (citing various justifications of regulation and "social costs" of high debt); Engel \& McCoy, supra, at 1262 (noting distributive justice and externality concerns in mortgage lending).

28. See, e.g., Christopher K. Odinet, Banks, Break-Ins, and Bad Actors in Mortgage Foreclosure, 83 U. CIN. L. REV. 1155, 1157-60 (2016). 
and other devices intended to aid injured consumers. ${ }^{29}$ Legal prohibitions often act as true constraints only when paired with these heightened sanctions and enforcement structures.

As with other constraints, legal constraints do not usually circumscribe actions as definitively as the clear line circumscribing this area in the diagram might suggest. Prohibition and enforcement, and ultimately deterrence, will be matters of degree. This important fact is considered further in Part IV.

\section{Social Constraints}

Second, consider the set of socially feasible actions (as labeled in Figure 1), those (1) for which public responsibility cannot be avoided, and (2) which, if known, would not be considered so contrary to governing norms of social behavior that a party wouldn't undertake them. ${ }^{30}$ The first element acknowledges that there are many actions that parties take behind closed doors that affect consumer commercial relationships but that are unlikely to ever be revealed. Some actions might draw social opprobrium if known, but parties engage in them because the risk of disclosure is low. The second element acknowledges that it is society's reaction that determines the level of deterrence produced by a given norm.

As with legal acceptability, it is not the case that an action is either socially acceptable or not - this is not a purely dichotomous condition. Some actions are vaguely distasteful but profitable enough to be worth the reputational cost. A rational merchant might decide to "hold its nose" and partake in such actions anyway. Such actions are socially feasible under this model because the model focuses on actions that are actually deterred by the threat of reputational harm. ${ }^{31}$

Social science literature on reputation has emphasized its power particularly in "close-knit" societies. ${ }^{32}$ Drawing from these insights, legal

29. See, e.g., Bradley, supra note 3 , at 83 (discussing and collecting sources discussing statutory damages); $i d$. at 72 (discussing and collecting sources concerning class actions and consumer protection).

30. On what is meant by "norms," see ELLICKSON, supra note 15, at 127. Basically, they are "rules that emanate ... from social forces." Id. In the social world studied by Ellickson (ranchers in Shasta County), the norms could be discerned from the fact that ranchers described them to him, that they actually abided by them, and that they "regularly punished, with gossip and ultimately with violent self-help, ranchers who failed to control their cattle." Id. at 130. Violent self-help is less common in the consumer context, but gossip in the form of reputational attacks on the Internet (sometimes in "violent" language) is a similar means of enforcing such norms.

31. Such actions could be mapped as close to the edge of the relevant circle, near what should be imagined as a blurry line at the edge of each oval.

32. See ElLICKSON, supra note 15, at 143, 166. 
scholars have suggested that formal legal sanctions take on greater importance where social bonds are weak. ${ }^{33}$ The classic example is the weaker social bonds of large cities as opposed to small towns. ${ }^{34}$

These insights are applicable to consumer transactions. Earlier work on consumer commerce has confirmed that traditional brick-and-mortar firms care about reputation among what often amounts to the "small town" of their customer base. ${ }^{35}$ They are more responsive to consumer complaints and interests than would be expected if their primary concern were only legal sanctions (e.g., warranty claims). ${ }^{36}$ These firms have long supported organizations such as the Better Business Bureau, to demonstrate and bolster their credibility with consumers. ${ }^{37}$ Today, large and stable firms doing business online attend to their reputation in a similar fashion. ${ }^{38}$ Established businesses, reliant on repeat customers and on reputation, are sensitive to social constraints - although, they too occasionally violate social norms and legal rules. ${ }^{39}$

33. See, e.g., ElLICKSON, supra note 15, at $39 \mathrm{n} .15$ (" [L] ack of a prospective long-term future relationship makes disputants less likely to resolve their differences without the help of third parties, and hence more likely to resort to legal and political action."); $i d$. at 94 (providing a summary chart).

34. Id. at 253 .

35. Id. at $141-43$ (discussing academic literature).

36. Id.; A. Mitchell Polinsky \& Steven Shavell, The Uneasy Case for Product Liability, 123 HARV. L. REV. 1437, 1443-50 (2010) examining the impact of market forces, including reputational concerns, on firms' decisions to redesign products); id. at 1449 ("[L]arge firms tend to be especially concerned about their reputation for safety because they often offer multiple product lines and have long time horizons."). There is a much broader literature in the business world concerning the importance of reputation for most traditional firms. See, e.g., Eugene W. Anderson, Claes Fornell, \& Sanal K. Mazvancheryl, Customer Satisfaction and Shareholder Value, 68 J. MARKETING 172, 183 (2004) (finding a positive association between reputation with customers and shareholder value). Anne Fleming has documented various relevant practices among "fringe financiers" in twentieth century New York. Compare ANNe Fleming, City of DeBTORS: A CENTURY OF Fringe FinANCE 158-59 (2018) (discussing the effective use of "grassroots protest" against Harlem merchants), with id. at 175 (noting the difficulty of enforcing consumer protective regulations or applying social pressure to "flyby-night" merchants and lenders, including those represented by "door-to-door" sellers), and id. at 145 (noting that consumers seeking remedies against door-to-door sellers of goods faced the often insuperable barrier of having to "track[ ] down a door-to-door seller to serve notice of the lawsuit").

37. See, e.g., id. at 150 (discussing the Better Business Bureau and noting its limitations); JAKE HALPERn, BAD PAPER: ChASING DEBT From WALl STREET TO THE UNDERWORLD 103-05 (2014) (discussing ease of appeasing the Better Business Bureau's complaint process without substantive compliance with regulations).

38. Cathy O'Neil, Weapons of Math Destruction: How Big Data increases INEQUALITY AND THREATENS DEMOCRACY 186-87 (2017) (noting that critique of American Express's use of customer data caused a change in course).

39. See infra note 56-57 and accompanying text (discussing the example of Wells Fargo). My treatment of this subject is, by necessity, brief. The issue deserves fuller treatment. There are some countervailing factors that might lead established companies to be more abusive of consumers. For instance, companies under distress will discount potential future business very aggressively and, thus, may be more willing to abuse current customers at the cost of future business. Or merchants may treat customers less well if they know those customers are "locked-in," i.e., reluctant to switch to a new, unfamiliar merchant unless extremely unhappy. See, e.g., DAVID Yosifon, CORPORATE FriCTION: HOW CORPORATE LAW IMPEDES AMERICAN PROGRESS AND WHAT TO DO ABOUT IT (2018) (discussing empirical evidence of such lock-in). 
By contrast, one might expect reputational constraints to be significantly loosened in a less close-knit commercial environment. ${ }^{40}$ In that respect, the Internet is far bigger than the biggest city. The Internet lowers the barriers to entry of any new actor, and permits anyone, anywhere in the world, to engage in business with online consumers across the globe. Many transactions are now completed with one-off merchant counterparties about whom the consumer has little information. ${ }^{41}$ Also, current U.S. business law permits cheap, easy, low-disclosure creation of limited liability entities. ${ }^{42}$ Some merchants (e.g., some shadowy online lenders) may be essentially disposable entities, used to engage in activities that their actual (hidden) principals might not want to undertake publicly in their own names. ${ }^{43}$ Because these actors care little about their reputation, social forces only marginally impact them. Disposable entities can be easily abandoned if negative public opinion overtakes them and hurts their business prospects. Then, the same business can be reborn under a different name with a reputationally "clean slate." For such entities, the realm of socially feasible actions may be quite broad. ${ }^{44}$

40. Notice, however, that "close-knit" does not always refer to geographical closeness at a particular time. For example, Ellickson provides an extended discussion of whaling norms, maintained despite the relatively far-flung activities of the various participants in the industry. ELLICKSON, supra note 15, at 191-206. But, of course, the parties have to see benefits in cooperation, and other conditions have to be met for such order to emerge.

41. I do not mean to suggest this is an entirely new problem; lenders have long used numerous evasions-including changing names and locations as needed - to escape regulatory and social sanction. Professor Fleming provides numerous, rich accounts of lenders using different corporate identities and (pretended) location to evade regulations and obscure the actors actually behind consumer lending transactions. See, e.g., FLEMING, supra note 36, at 27, 56. But the problem seems particularly acute in the online world, where the marketplace is global, and masking identity is very easy.

42. See, e.g., Charles R.T. O'Kelley \& Robert B. Thompson, Corporations and Other BUSINESS ASSOCIATIONS 533-37 (2017) (presenting basic aspects and history of limited liability companies (LLCs) under modern business entity law); Patricia Cohen, Need to Hide Some Income? You Don't Have to Go to Panama, N.Y. TIMES (Apr. 7, 2016), https://www.nytimes.com/2016/04/08/business/need-to-hide-some-income-you-dont-have-to-go-to-panama.html (noting minimal Delaware LLC disclosure laws).

43. See, e.g., BAR-GILL, supra note 19 , at 28 (noting that some consumers intentionally select merchants at the lower end of the market, but may not take account of lower-quality contract design features selected by "sellers" who are "undeterred (or less deterred) by the threat of a reputational penalty"); HALPERN, supra note 37, at 168 (recounting concerns of New York state regulator that companies would simply "reopen somewhere else under a different name," to obtain lighter regulation); $i d$. at 221 (providing examples of the rapid closing and reopening of businesses under new name or in new location); PETERSON, supra note 18, at 135 ("[B] ecause entry and exit costs are low for highcost creditors, the market is inundated with fly-by-night businesses that make only minor investments in reputational capital and other sunk costs. Because many high-cost lenders do not invest time and effort in building solid reputations, they have little to fear from word-of-mouth criticism." (footnote omitted)).

44. BAR-GILL, supra note 19, at 165 (noting that problems "in the subprime mortgage market" including the lack of "repeat business, as a single borrower takes few mortgage loans and a relatively long time passes between loans," as well as "the opening of the market [by the rise of securitization] to fly-by-night originators with little reputation to lose and insufficient incentives to build a reputation"); see, e.g., Engel \& McCoy, supra note 27, at 1289-90 (contrasting "[b]anks and thrifts," which are "community institutions with valuable reputations," with "[p]redatory lenders [who] are less concerned about their reputations because they are simply conduits, not community institutions," and who "can readily dissolve and re-emerge in the same communities under different names"); $i d$. at 1353 (discussing "fly-by-night operations" of some predatory lenders, who have "little capitalization" and 
Finally, due to technological developments, online merchants may be able to prevent consumers from becoming aware of certain practices. For instance, consumers have not yet caught on that merchants are using advanced technological tools to set pricing, anticipate consumer needs and desires, and otherwise leverage Big Data to ensure that transactions take place on the most advantageous terms possible for the merchant. ${ }^{45}$

On the other hand, new forms of social constraint have begun to emerge that may affect this state of affairs. Social media and online review sites may be able to provide some "bite" to reputation - even in a changed world. ${ }^{46}$ These online platforms can serve effectively as forms of pervasive public surveillance of businesses. How best to cultivate, or constrain, these and other policy tools deserves further exploration. ${ }^{47}$

In sum, social constraints may have diminished in some arenas-particularly one-off, purely online transactions with unknown or anonymous counterparties - and thus, new areas of permitted action may have opened; in others, the realm of social acceptability has narrowed thanks to the public scrutiny facilitated by the Internet. ${ }^{48}$ But in all cases, it is an important factor affecting merchant and consumer behavior, and one that merits particularized policy attention.

\section{Technical Constraints}

Third, consider the set of technically feasible actions (as labeled in Figure 1), which are those that, as of a particular moment in time, are (1) technologically possible and (2) can be deployed in a cost-effective

"can dissolve and reincorporate, sometimes in other states, practically overnight"); $c f$. Engel \& McCoy, supra note 27, at 1296 ("Some banks and thrifts, whose direct lending is legitimate, have subsidiaries and affiliates that employ predatory lending practices."). Professor Odinet has provided an additional example of when reputational constraints can be ineffective: when the market has collapsed and there is no need to worry about obtaining future business. See CHRISTOPHER K. ODINET, Foreclosed: Mortgage Servicing and the Hidden ARChiteCture of Homeownership IN AMERICA 55 (2019) (" $[T]$ here was very little market incentive for servicers of subprime [mortgage] loans to do a great job for reputational reasons. One would think that having a good name on Wall Street would lead to future servicing businesses. However, in the wake of the crash this was simply not the case. . . Because the business model of servicing subprime loans was essentially headed down the toilet, there was no reason to compete for future business-and thus no real reason to strive for excellent in servicing the loans that were quickly going into default."). This issue is discussed in greater detail at infra Part IV.A, where I acknowledge that a path for future work is to distinguish what laws and policies might be appropriate for different types of merchants, in part based on their different levels of responsiveness to sanctions, including reputational/social sanctions.

45. Rory Van Loo, Helping Buyers Beware: The Need for Supervision of Big Retail, 163 U. PA. L. REV. 1311, 1347-49 (2015).

46. See Rory Van Loo, The Corporation as Courthouse, 33 YALE J. ON REG. 547, 569-71 (2016). The potential for such tools was foreseen by ELLICKSON, supra note 15, at 285 writing in 1991 that "recent advances in data processing make it easier to store and retrieve truthful public-record information about a person's previous failures to cooperate.... [T] he improved circulation of accurate reputational information can deter fly-by-night opportunism."

47. See, e.g., Arbel, supra note 19. Professor Arbel provides a skeptical view of the effectiveness of technology-driven reputation constraints absent regulatory intervention, and proposes convincing "fixes" for this market failure.

48. See supra note 46 and accompanying text. 
manner in consumer transactions. The set excludes acts that are not technologically possible (e.g., reading your mind to assess your willingness to repay a loan you have applied for); or that are possible but too expensive or inconvenient to be worth it (e.g., interviewing your friends and family to ascertain your intentions regarding repayment).

Stated differently, the boundaries - the circumference - of that ellipse represent technical constraints on commerce. ${ }^{49}$ These constraints have nothing to do with the legality of actions, or the state of the law; nor do they involve social acceptability and the reputational effects of engaging in a course of action. Instead, these constraints involve only whether a market participant, independent of regulation and social context, might find them cost-effective pursuits. Unlike legal and social constraints, technical constraints may not even be recognized as constraints until technology has already overcome them-in other words, until technology shifts the boundaries of what we consider "possible," we might not have realized what we were missing. Perhaps the world would be better if more of those technical constraints were surmounted. This is plausible with respect to many forms of technical limitation. But even desirable shifts have complex and important implications for policy.

The category of technical constraints is intended to be broad. It is helpful to consider not just "advanced" technological actions, such as procuring Big Data about consumer behavior on the Internet. Rudimentary technologies - many of which have been around for decades, such as telemarketing, bar codes, and even adhesion contracts - remain relevant technologies in setting the scope of feasible acts in consumer commerce. ${ }^{50}$ Often, technologies developed for other purposes end up having unintended but important effects on commercial transacting. For example, advances in data storage and computer networking have provided merchants and consumers with greater access to banking records (such as images of

49. The use of the term "technical" at many points in this Article is intended to indicate that some of the constraints might not be what is colloquially thought of as "technological" but rather natural/physical, in nature. See, e.g., Davis, supra note 24, at 85 (defining "technology" broadly to include production knowledge). Globalization, for instance, can be thought of as a loosening of "technological constraints" in the form of increasingly more efficiently organized long-distance commercial networks (it also, of course, relies on relaxed legal constraints). Professor Surden has provided a more thoroughly elaborated analytical framework concerning "non-legal regulatory devices"; for instance, he uses the more general term "structural constraints" to mean roughly what I term "technical constraints," and then he subdivides that category in interesting ways. See generally Surden, supra note 23, at 1606-08; see also Surden, supra note 15, at 138 ("This Article proposes the term 'Technological Cost' to capture how activities can be implicitly constrained by limitations inherent to technological processes of the past.").

50. Christopher G. Bradley, Disrupting Secured Transactions, 56 Hous. L. REV. 965, 1028 n.177 (2019) (discussing importance of bar code); Bradley, supra note 3, at 78-79 (noting that technological changes can take considerable time to impact markets and social norms). It has been aptly said that "technological revolutions do not get interesting socially until they are boring technologically." Joshua Fairfield, Smart Contracts, Bitcoin Bots, and Consumer Protection, 71 WASH. \& LEE L. REV. Online 35, 47 (2014) (citing Clay Shirky, How Social Media Can Make History, TED (June 2019), http://www.ted.com/talks/clay_shirky_how_cellphones_twitter_facebook_can_make_history/transcript (stating that online "tools don't get socially interesting until they get technologically boring")). 
deposited checks and payment histories); ease of access, in turn, has had numerous important effects on the financial system, for good or ill. ${ }^{51}$

Finally, in this category, there is a special case that should be considered: an action that is technically possible for one party but is easily countermanded by technology available to the other party. ${ }^{52}$ An example is the pop-up advertisements generated by Internet websites. ${ }^{53}$ These ads were sufficiently effective as to become widespread, but they also caused great annoyance to consumers, who commonly found themselves unable to close websites because of an endless proliferation of pop-ups. Then, blockers of these ads were developed and became widespread, such that pop-up ads may no longer be considered a technically feasible option because they are so widely and easily thwarted. ${ }^{54}$ As will be discussed in later sections of this Article, consideration of such countermeasures is a way in which this model can be refined for the analysis of particular fact scenarios.

\section{B. Reading the Model}

The fundamental principle of this model, stated in plain language, is this: Only if an act is technically, legally, and socially feasible will a participant engage in it. Consumers are effectively "protected" from all other acts.

This principle can be represented as in Figure 2 below. Let legally feasible actions be defined as the area $F_{L}$, technically feasible actions be defined as the area $F_{T}$, and socially feasible actions be defined as the area $\mathrm{F}_{\mathrm{S}}$. The scope of permitted actions is defined as the area at the intersection of these three types of feasibility: PA. In other words, as shown below, $P A=F_{L} \wedge F_{T} \wedge F_{S}$.

51. Bradley, supra note 3, at 72, 92-94 (discussing literature on effect of technologically tethered consumer finance activity on those lacking digital literacy).

52. Some of the relevant issues are discussed well by Eric Goldman, A Coasean Analysis of Marketing, 2006 WIS. L. REV. 1151, 1152-53, 1156, 1220 (2006).

53. See, e.g., John Herrman, Google Chrome Now Blocks Irksome Ads. That's a Good Thing, Right?, N.Y. TIMES (Feb. 18, 2018), https://www.nytimes.com/2018/02/18/business/media/googlechrome-ad-block.html (describing Internet advertising that is easily thwarted by ad-blocking software).

54. See, e.g., Lauren E. Willis, Why Not Privacy by Default?, 29 BerKelEy TeCH. L.J. 61, 7071 (2014) (discussing antitracking technologies); Klint Finley, Google's New Ad Blocker Changed The Web Before It Even Switched On, WIRED (Feb. 16, 2018, 7:00 AM), https://www.wired.com/story/google-chrome-ad-blocker-change-web/ (noting that a 2016 survey "found that about 26 percent of web users had installed ad-blockers on their computers," and that Google Chrome's default blocking of some pop-up ads may be intended to stop users from installing more aggressive products that threaten Google's own advertising revenue); Herrman, supra note 53 (describing Google's imposition of default pop-up detection and blocking software in its Chrome browsers). 


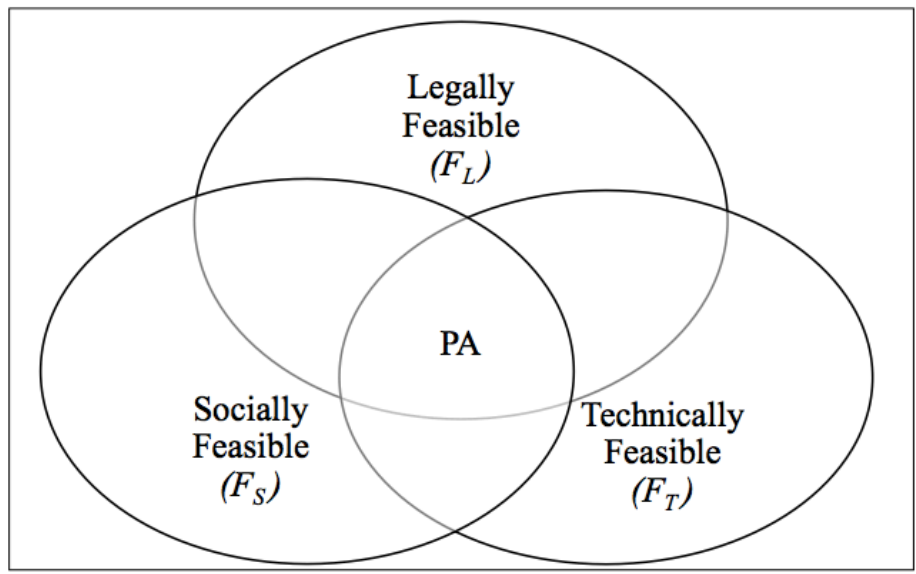

Figure 2 .

The most obvious and important observation emerging from Figures 1 and 2 is that consumers are protected by social, technical, and legal constraints. This model is a realist one because it focuses on the broader social and practical realities, wherein legal prohibitions and institutions play important but limited roles. ${ }^{55}$

A simple example from recent headlines: It is technically possible to open bank accounts for large numbers of customers without their permission, as Wells Fargo has admitted doing. ${ }^{56}$ But it is both unlawful and socially unacceptable to do so. As noted, however, social and legal sanctions deter behavior only when the behavior is likely to become known. Wells Fargo's conduct went undetected for a considerable length of time, and those engaging in this conduct may have assumed that it would remain undiscovered. Because Wells Fargo's conduct was revealed and has been heavily sanctioned, future market participants are likely to be deterred for both social and legal reasons. ${ }^{57}$

The key premise of this realist model of the consumer protection ecosystem is that, whether recognized or not, technical and social constraints form a crucial part of the boundary of the effective scope of actions that

55. This insight has been demonstrated amply in the work of social science-oriented scholars, see, e.g., infra note 36 , but has not sufficiently been taken into account in consumer protection discussions.

56. See Michael Corkery, Wells Fargo Fined $\$ 185$ Million for Fraudulently Opening Accounts, N.Y. TimeS (Sept. 8, 2016), https://www.nytimes.com/2016/09/09/business/dealbook/wells-fargofined-for-years-of-harm-to-customers.html?auth=login-email\&login=email.

57. See id. (describing sanctions); Matt Egan, Wells Fargo's Scandals Are Hurting Its Bottom Line, CNN BUSINESS (July 13, 2018, 11:04 AM), https://money.cnn.com/2018/07/13/news/companies/wells-fargo-earnings-stock/index.html. 
participants in consumer transactions may take at a given time. A constraint is a constraint. ${ }^{58}$ All forms of constraint constitute important aspects of "consumer protection."

This is not to say that each type of constraint operates in the same way. Technical constraints may take the form of an arms race or a cat-andmouse game as parties develop technical capacities that essentially cancel each other out - or at least dampen the effects of new tools. ${ }^{59}$ Violations of legal constraints may be subject to different norms or beliefs than technical ones. Willful, public violation of a legal constraint may be viewed in some cases as the product of an intentional and legitimate political or expressive act, and may even lead to legal change. Alternatively, such an action may be viewed with intensified social opprobrium because it is not only wrong but also illegal. ${ }^{60}$ Other nuances regarding these different constraints are discussed in Part IV.A below. This area is another aspect of the model that is ripe for refinement, particularly by interdisciplinary research.

\section{A Taxonomy of Consumer Commercial Actions and Constraints}

The model presented above permits a taxonomy of potential actions to be made, and allows for analysis of the relationship between these different constraints on consumer commerce. Figure 3 depicts the complex interrelationships among these constraints. Each area within the Venn diagram presents a distinct unit of analysis. I provide real-world examples of actions in each area below.

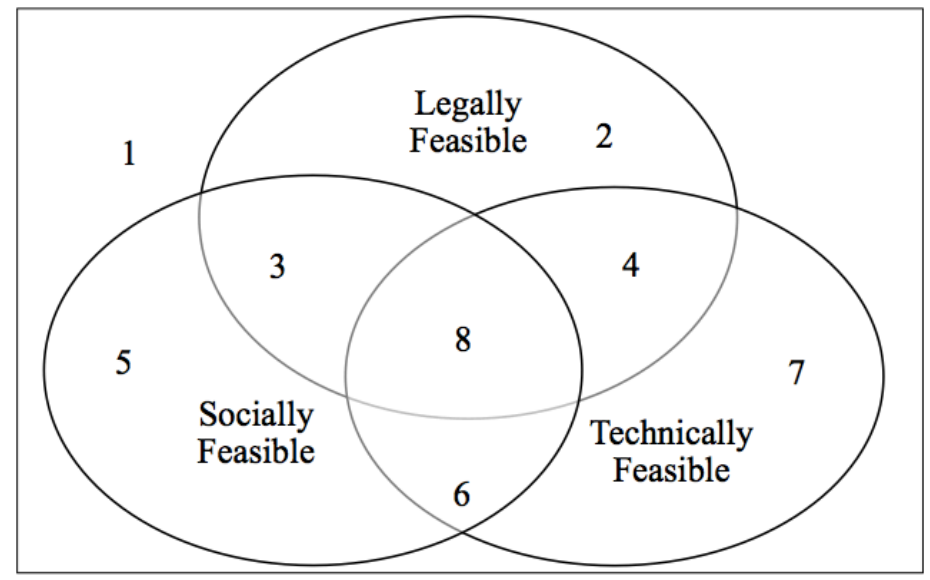

Figure 3 .

58. To put it in the famous words of proto-legal realist Oliver Wendell Holmes, these are all constraints that would operate on "the bad man." See O. W. Holmes, The Path of the Law, 10 HarV. L. REV. 457, 460-61 (1897).

59. The law has been characterized, similarly, as a "tug of war," as it is perceived to have gone too far in one direction or the other and as changing political tides take it one direction of another. SPANOGLE ET AL., supra note 11.

60. See supra note 15 and accompanying test (discussing "code as law"); see supra Part II.A.1. (discussing the literature on the special features of (il)legality as a particular type of constraint). 
The areas within the Venn diagram are as follows:

Area 1: Actions that are outside the bounds of legal, social, and technical feasibility.

Area 2: Actions that are legal but neither socially acceptable nor technically feasible.

Area 3: Actions that are socially acceptable and legal but are not technically feasible.

Area 4: Actions that are legally and technically feasible but are not socially acceptable.

Area 5: Actions that are socially acceptable but are neither legally nor technically feasible.

Area 6: Actions that are socially and technically feasible but are illegal.

Area 7: Actions that are technically feasible but are neither socially acceptable nor legal.

Area 8: Actions that are legal, socially acceptable, and technically feasible.

There is room for judgment in determining which area a given action falls in. There may be differences of opinion in whether a given action is actually socially acceptable (given the different communities that might be called upon to judge it), or legally feasible (given the varied legal regimes and enforcement possibilities), or even technically feasible (given the degrees to which parties' technical capacities might differ). But even if they are contestable, examples in each category helpfully illuminate the scope and variety of what this model includes.

Area 1: Actions that are outside the bounds of legal, social, and technical feasibility.

At first glance, this might seem to be a fanciful category. It is difficult to look prospectively and predict what will become feasible as a matter of later technical, legal, or social change. However, helpful examples can be found if searched for retrospectively and with the benefit of hindsight.

A simple thought experiment helps give the category meaning. Consider an advertiser who wishes to gain direct, near-real-time access to vast amounts of highly personal information about an individual and her friends. This advertiser wants the information to discover, for instance, the 
week that the individual learns she is pregnant to sell her pregnancy-related products (and peddle her information to others). ${ }^{61}$ In the late 1990s or early 2000s, it would have been unlawful, socially unacceptable, and technically infeasible to do such a thing. However, such data-mining activities are commonplace today thanks to a variety of legal, social, and technical changes. ${ }^{62}$ Now, such behavior may be in Area 8 (for better or worse). But not too long ago, it would have been in Area 1. It is difficult to predict what the next battlegrounds might be, but they may be as unpredictable to us now as Big Data was a few decades ago.

Area 2: Actions that are legal but neither socially acceptable nor technically feasible.

Again, it is difficult to propose plausible examples that are not currently technically feasible. However, one example is the use of credit reports and credit scores in commonplace, small-scale commercial transactions. Trade vendors such as plumbers or locksmiths often extend unsecured credit by providing services and receiving payment or invoicing the customer afterwards. While consumers expect their credit to matter for large purchases, they would resist a check in advance of a visit for a routine service call. Such checks would be legal, but likely socially unacceptable.

These checks might not be technically feasible either, at least for small home repair businesses. It would be relatively expensive and cumbersome to perform a credit check over the phone prior to dispatching workers to each service call. Performing a check after the fact would be too late, because the call's expense would have already been incurred.

Thus, such a credit check, while lawful, would likely be both socially unacceptable and - for the moment - technically infeasible. One could, however, imagine this type of check becoming both more technically feasible and socially acceptable in the future.

Area 3: Actions that are socially acceptable and legal but are not technically feasible.

61. See Sarah Gray, One Woman's Attempt to Hide her Pregnancy from Big Data-It's More Difficult Than You'd Expect, SALON (Apr. 29, 2014, 2:45 AM), https://www.salon.com/2014/04/28/one_womans_attempt_to_hide_her_pregnancy_from_big_data/ (noting that "[t]o marketers, the average Joe's online data is worth around 10 cents. However, a pregnant woman's data is worth fifteen times that: $\$ 1.50$ ").

62. See, e.g., Charles Duhigg, How Companies Learn Your Secrets, N.Y. TimES MAG. (Feb. 16, 2012), https://nyti.ms/AyNgCY (discussing Target's aggressive use of data procurement and analytics in determining pregnancy status of customers, but also noting Target's sensitivity to the potential public-relations risks and some potential legal risks of their strategies); Rachel Emma Silverman, Bosses Tap Outside Firms to Predict Which Workers Might Get Sick, WALL ST. J., https://www.wsj.com/articles/bosses-harness-big-data-to-predict-which-workers-might-get-sick-1455664940 (last updated Feb. 18, 2016) ("Employee wellness firms and insurers are working with companies to mine data about the prescription drugs workers use, how they shop and even whether they vote, to predict their individual health needs and recommend treatments."). 
These are actions that merchants and consumers are merely waiting for technology companies to facilitate. Drone-based product deliveries ${ }^{63}$ and virtual-reality shopping ${ }^{64}$ (or even virtual fitting of clothes ${ }^{65}$ ) provide ready examples. These actions currently lie on the other side of the border of technical feasibility but may cross to our side soon. Once the technical solution is found, legal and social barriers are unlikely to influence adoption (although whether they will catch on is a business question).

\section{Area 4: Actions that are legally and technically feasible but are not socially acceptable.}

This category includes actions that are only constrained by social norms. Some might assume that the law would prohibit most socially unacceptable acts and that examples of this category would be hard to find. In fact, there are many. Consider when airline employees had a doctor dragged off an overbooked United Airlines flight after he had taken his seat. Passengers recorded his forcible removal and quickly posted those videos on social media. ${ }^{66}$ While the actions of the airline were technically feasible, and at least arguably in accord with governing law, the ensuing firestorm of bad publicity made clear that the act was over the bounds of social acceptability - and, in the age of mobile devices and viral videos, it could not be hidden from public view. As a reminder, the category of socially permitted actions is defined to include actions that would draw disapproval if known, but that can be concealed. As this example shows, certain actions may be rendered more discoverable over time, particularly with the rise of social media, easy data-sharing, and camera-phones. Accordingly, the scope of acceptable actions may constrict.

By contrast, some consumer protection experts are skeptical of the disciplining effects of reputation in the world of Big Data because companies can successfully mask their actions, divert consumer attention, and avoid criticism. For instance, retailers have become adept at masking their tailored, surveillance-based advertising and marketing efforts at just below the threshold of what consumers might find alarming. ${ }^{67}$ Some retailers seeking to determine optimal prices for profit maximization have pursued

63. Jeremy Lin \& P.W. Singer, Meet China's Growing Fleet of Automated Delivery Drones, POPULAR SCIENCE (July 3, 2018), https://www.popsci.com/china-drone-deliveries ("Alibaba, China's largest e-commerce firm, is already making drone deliveries in Shanghai.").

64. Anthony Soohoo, Walmart.com to Introduce New Home Shopping Features: $3 D$ Virtual Shopping Tour and "Buy The Room", WALLMART (June 27, 2018), https://corporate.walmart.com/newsroom/2018/06/27/walmart-com-to-introduce-new-home-shopping-features3d-virtual-shopping-tour-and-buy-the-room.

65. See 4D Movies Capture People in Clothing, Create Realistic Virtual Try-On, MAX PLANCK INST. FOR INTELLIGENT SYS. (Aug. 1, 2017), https://www.is.mpg.de/news/4d-movies-capture-peoplein-clothing-creating-realistic-virtual-try-on (discussing "ClothCap," or "clothing capture" technology that uses video-obtained analysis of clothing data to assess sizing and fit).

66. Camila Domonoske, Passenger Forcibly Removed from United Flight, Prompting Outcry, NPR (Apr. 10, 2017, 12:50 PM), https://www.npr.org/sections/thetwoway/2017/04/10/523275494/passenger-forcibly-removed-from-united-flight-prompting-outcry.

67. See, e.g., Van Loo, supra note 45 at 1322, 1348 (offering the example of Target responding to criticism by masking its Big Data advertising to maintain it "under the threshold of awareness"). 
highly technical, and privacy-invasive, strategies: "Mass retailers continually fine-tune their pricing algorithms through advanced behavioral datamining operations. They film customers' in-store movements, compile loyalty card data, and conduct many randomized controlled trials that easily provide statistical significance across thousands of stores and millions of transactions." ${ }^{68}$ Retailers using these or a panoply of other Big Data tools may eventually draw the ire of consumers - or, alternatively, be viewed as perfectly acceptable if privacy norms continue to erode ${ }^{69}$ For now, these retailers' actions remain unknown to, or poorly understood by, the general public, and are not socially constrained.

A final point: as the diagram itself handily reflects, there is a shared border between this area and Area 8 (the actions that are legally, technologically, and socially feasible). It may be the case that a way for a company to "game" the line between these two areas is to switch to a more socially acceptable practice after the fact and on a case-by-case basis, only for the benefit of customers who complain. Thus, as scholars have noted, businesses can use "the customer service department as a site of displaced bargaining about the less salient terms of adhesive contract," such as exorbitant late fees or interest charges. ${ }^{70}$ When such gambits are successful, businesses can be thought of as having successfully evaded constraint in all but the relatively few instances of customers challenging it.

\section{Area 5: Actions that are socially acceptable but are neither legally nor technically feasible.}

One example of this type of action is in the sphere of online comparison shopping and competition for provision of financial services. Remarkably, price comparison platforms are often barred from gathering price information from merchants offering goods on the Internet both due to laws and due to technological obstacles erected by sellers of goods. ${ }^{71}$ Similarly, "legacy" financial institutions have erected technical barriers and cited legal prohibitions to bar innovative financial services providers

68. Id. at 1322 ("Retailers track micro-behavioral patterns such as variations in consumers' price sensitivity by item at different times in different stores and adju, st prices accordingly. Online retailers also selectively charge consumers higher prices by, for example, profiling operating systems and tracking purchase history." (citations omitted)); id. at 1345 ("Using technology that shows where the eye is looking, retailers have determined where most consumers naturally look when they walk down an aisle ... [R] etailers can anchor the consumer at a higher price so that subsequent items appear cheaper by comparison.").

69. See generally id. at 1331-33. Professor Van Loo's article is a fascinating compendium of examples of how technology has enabled all sorts of new forms of merchant behavior.

70. Van Loo, supra note 46, at 280 (discussing consumers who are likely to receive the superior treatment afford to "squeaky wheel" customers). I am grateful to Professor Van Loo for helping me see the relationship of this scholarship to business practices at the Area 4/Area 8 border.

71. See Rory Van Loo, Digital Market Perfection, 117 MICH. L. REV. 815, 837 (2019) (“Counterintuitively in the information age, businesses can block access to market information that exists openly on the web, such as Amazon's or airlines' prices. ... Online sellers have used the Computer Fraud and Abuse Act (CFAA) and other laws to forbid third parties from digitally collecting such information." (internal footnotes omitted)); see also id. at 836-45 (describing the range of "legal and market battlegrounds" on which would-be new "digital intermediaries" have had to fight to obtain access to new markets). 
from accessing customer account information; thus, they have hindered startup financial technology (FinTech) companies from competing with them. ${ }^{72}$ These technical and legal constraints hinder new competitors from activities that would otherwise be acceptable.

A more controversial example of this category is merchants who would take actions adverse to some socially disfavored but legally protected part of the population - if they could readily distinguish members of that group. Such a merchant might not be subject to any social sanction in the area they are located or from the community of their customers. But implementing this policy would be illegal and would also present technical difficulties. ${ }^{73}$ Of course, some businesses might find a way of sorting potential customers into the disfavored group. In that situation, where the discrimination is both technically and socially feasible, legal protection attains its greatest importance because it is the only remaining constraint. That situation falls in Area 6, considered immediately below.

\section{Area 6: Actions that are socially and technically feasible but are illegal.}

This category includes actions that are prohibited by law but that the general public would not understand the abusiveness of, or would not consider problematic because the law protects a socially disfavored part of the population (as in the last example above).

This category also includes actions that are illegal but should not be - that is, actions prohibited by vestigial regulations that are in need of repeal. Some businesses in the "gig economy," such as Uber and AirBnb,

72. See Rory Van Loo, Making Innovation More Competitive: The Case of Fintech, 65 UCLA. L. REV. 232, 242-43 (2018) (describing barriers to entry imposed by "legacy" firms, including use of dominant market positions and of laws such as the Digital Millennium Copyright Act, which were intended to protect customer data against misuse rather than protect banks from competition); id. at 261-64 (noting antitrust implications of legacy firms' conduct).

73. Consider discrimination on the basis of categories such as religion or sexual orientation that may be relatively difficult to detect in a particular customer. There are probably merchants (similar to the baker in the recent Supreme Court case, Masterpiece Cakeshop, Ltd. v. Colo. Civil Rights. Comm'n, who would discriminate against members of these various protected classes if possible, despite such conduct being unlawful under federal, state, and local law(s). 138 S. Ct. 1719 (2018)). But such merchants often have no idea whether many of their customers fall into the class, and in most instances, no ready way of finding out. Such merchants are both legally and technically constrained from taking an action that - to them-would not be barred by social constraints or fear of reputational harm. This is an important example to reinforce a point emphasized below. See infra Part III.A. Social acceptability may constrain some but not all merchants in a community, and so to some degree the model's analysis has to be customized to consider different subcommunities or simply different degrees of responsiveness to this form of constraint (which sometimes may be more and sometimes less cutting than legal constraints). Also, consider the party harmed by the merchant discussed here: It would be of limited comfort to the would-be customers in Masterpiece Cakeshop to tell them that while the business they tried to purchase a wedding cake from had the technical ability to discriminate against them, many businesses (their local paint supply store or tire shop or whatever) would be constrained from doing so by being unable to discern their sexual orientation in time to refuse to deal with them. Thus the type of transaction and the characteristics of the protected consumers may vary, too, in ways worth disaggregating in order to reach good policy results. 
have disregarded arguably outdated taxi licensing laws, and have been met with considerable business success. ${ }^{74}$

On a more old-fashioned note, it is technically feasible for a company to send collectors dressed as Zorro to harass debtors in arrears, and it is socially acceptable to do so in some communities - including Spain. ${ }^{75}$ But it is decidedly not legal (any more ${ }^{76}$ ) in the United States, ${ }^{77}$ even if it might be technically possible and even, perhaps, socially acceptable.

In fact, this category may include many of the contentious areas of consumer finance in recent years. ${ }^{78}$ The ways in which interest payments are calculated, credit-insurance products are sold, disclosures are crafted, and various penalties and costs are applied, are sufficiently complex that the public may struggle to understand them, much less be outraged by them, even if they are unlawful. ${ }^{79}$

In other words, some practices engaged in by lenders in consumer financial transactions may be illegal but fail to attract public outrage because they are too difficult to understand or explain. ${ }^{80}$ This category seems to be a particularly important and intractable one from a regulatory perspective because it is where legal constraints operate on their own, unaided by other forms of constraint. Thus, this category deserves particular policy attention; tools and institutions designed to regulate complex areas such as

74. On the business model of these companies, which has been characterized as "regulatory entrepreneurship." See Elizabeth Pollman \& Jordan M. Barry, Regulatory Entrepreneurship, 90 S. CAL. L. REV. 383, 385 (2017). Broad and unnecessary occupational licensing laws also furnish good examples. See, e.g., Aaron S. Edlin \& Rebecca Haw Allensworth, Cartels by Another Name: Should Licensed Occupations Face Antitrust Scrutiny?, 162 U. Pa. L. Rev. 1093, 1102 (2013).

75. Aggressive and flamboyant debt collection practices - such as harassing debtors at their homes and businesses while dressed as Zorro, a monk, or a clown - are permitted in Spain but not England, because, according to one would-be debt collector, the English "are a bunch of wimps." See Jon Sindreu, Spain Has a Debt Problem and So Now It Has a Zorro Problem, Wall St. J. (July 28, 2017, 12:16 PM), https:/www.wsj.com/articles/spain-has-a-debt-problem-and-so-now-it-has-azorro-problem-1501172207. No doubt the collector would feel similarly about Americans.

76. While I know of no evidence of this particular practice having been pursued by collectors on these shores, it bears noting that more aggressive practices were long condoned here. See, e.g., FLEMING, supra note 36 ("Known as 'bawler-outs,' female debt collectors tracked down the delinquent borrower at home or work and loudly criticized him for his failure to pay back the money borrowed.").

77. The activities described would likely violate numerous provisions of U.S. law, including numerous sections of the Fair Debt Collection Practices Act, 15 U.S.C. $§ 1692$ (2018), not to mention relevant state laws.

78. See, e.g., PETERSON, supra note 18, at 149 (describing complex, "abusive" fees added, sometimes illegally, to some "high-cost" mortgages).

79. Professor Willis has described, for instance, the panoply of sophisticated ways in which financial institutions responded to regulation mandating that banks force consumers to opt-in to (rather than opt-out of) fee-based overdraft protection, largely complying with the letter but undermining the policy goals of the law. Willis, supra note 27, at 1183-1200; see also BAR-GILL, supra note 19, at 66 (noting complexity and number of credit card fees). Professor Bar-Gill also notes that contract terms (such as dispute resolution limits) can be put into contracts even by sellers with "high-quality products and reliable customer service." BAR-GILL, supra note 19, at 28.

80. Similarly, there is some evidence that consumers simply misunderstand some merchant practices or legal protections, particularly with respect to privacy. See Willis, supra note 54, at 73 ("Most consumers falsely believe that the law significantly restricts collection of consumer information and that the existence of a 'Privacy Policy' means their information is not shared with third parties." (citations omitted)). 
consumer finance must be tailored to the social and technical context of such transactions, or they risk ineffectiveness.

Area 7: Actions that are technically feasible but are neither socially acceptable nor legal.

A variety of actions might fall into this category-including most misuses of the powerful information technologies that are in the hands of businesses engaging with consumers online. One obvious example, already mentioned above, is Wells Fargo's opening of accounts in customers' names without consent and imposing unwanted and unneeded charges on auto loan customers. ${ }^{81}$ Such actions were obviously technically possible, but they ran afoul of the law as well as of social norms. Virtually any other technological capacity could be similarly abused, and the actor in question might face both legal and social sanctions. ${ }^{82}$

Area 8: Actions that are legal, socially acceptable, and technically feasible.

This final category is the intersection of the three categories of feasible actions - actions that are not effectively constrained by any of the three types of constraint. It is the category of permitted actions (PA). It is the area within which most of the behavior actually engaged in by consumers and merchants falls. This area includes acts that are legally prohibited but are not subject to effective enforcement; or acts that are unsavory and socially unacceptable but so difficult to detect that market participants are undeterred from engaging in them.

Importantly, an act that falls in this category is not necessarily benign. Old-fashioned practices such as charging very high interest rates and imposing high penalties remain common, yet many consumer advocates would prefer that not to be the case. Technology has enabled all sorts of newfangled practices, such as merchants' using Big Data to monitor consumers' moods and target them with sales pitches when they are least likely to be cautious or frugal. ${ }^{83}$ Such practices, when they become known, may eventually be thought violative of social norms; but they are not now (or they are engaged in covertly and, thus, cannot draw sufficient opprobrium). Assessing whether these various behaviors should be condemned socially or legally is beyond the scope of this model.

The examples above illustrate each of the eight areas contained in this model. There might be disagreements over the areas in which some of

81. See, e.g., Stacy Cowley, Wells Fargo Review Finds 1.4 Million More Suspect Accounts, N.Y. Times (Aug. 31, 2017), https://www.nytimes.com/2017/08/31/business/dealbook/wells-fargoaccounts.html? $\mathrm{r}=0$.

82. Other behaviors do not, but at some point, could, fall in this category if laws were better enforced (legally constraining them), or if public awareness were higher (socially constraining them).

83. Lauren E. Willis, Performance-Based Consumer Law, 82 U. CHI. L. REV. 1309, 13201322 23 (2015) ("With big data and the presence of computers, cell phones, and other devices intermediating consumer transactions, firms can tailor marketing, products, and prices to a single consumer in real time."). 
these examples should be located. As will be discussed in more detail below, social acceptability is not an either/or proposition, and legal and technical feasibility are also subject to debate in some cases. But at a minimum, and notwithstanding some play at the joints, the examples demonstrate that a wide variety of different types of acts, and varying combinations of constraints, exert force on those acts. All can be mapped on this model.

It can be readily seen how, as you consider the appropriate policy response to a particular act, the response will be guided, in part, by where you locate that act in this model. In some cases, social or technical steps might be sufficient to raise the "price" on a particular act. In other cases, for instance where a socially disfavored or technically less capable group is likely to be targeted, legal intervention will more likely be necessary. Parts III and IV of this Article explore some of these issues. First, however, the next Section explores the justifications for, and premises of, the model.

\section{Why a Model of "Consumer Protection"?}

This model provides a basic description of the consumer protection ecosystem and is intended as a starting point - a way of better structuring discussion over appropriate policy strategies and outcomes. It focuses on permitted actions in consumer transactions, taking a functional and applied approach to the constraints on the behavior of participants in such transactions. Later, Part III of this Article will explore ramifications of this model, and Part IV will address potential objections to it and discuss ways it can be refined and expanded upon in future work. The remainder of this Part provides some necessary background on the premises for the model and the reasons it is needed.

Taking a step back, then: Why are consumer commercial relationships different? Why do we need a separate model for them? Consumer transactions present complicated policy problems for several reasons.

Outside of the consumer arena, standards of business and commercial affairs are largely founded on expectations of repeat-dealing and reciprocity ${ }^{84}$ The law generally relies upon the assumption of sophistication, permits liberal freedom of contract, and applies doctrines such as caveat emptor to such transactions.

By contrast, businesses that engage in consumer transactionswhich, for convenience, this Article simply refers to as "merchants"-are

84. The locus classicus on the relational underpinnings of standard business-to-business transactions is described in Stewart Macauley, Non-Contractual Relations in Business: A Preliminary Study, 28 AM. Soc. REv. 55, 55 (1963). For a survey of subsequent literature, see Macauley \& Mertz, supra note 14. 
on a different footing with respect to consumers. ${ }^{85}$ Merchants deal with consumers who have a wide variety of tools, expectations, and capabilities. In addition, often the merchant will be the only repeat player in a commercial transaction; consumers often deal with a particular merchant or purchase that merchant's product on a one-off basis, or, at most, a sporadic basis. For example, individuals buy houses or cars, or take out student loans, only a few times in their lives, at most; whereas sellers and lenders engage in such transactions many times a day. For this reason, merchants attain greater sophistication concerning the legal and financial nuances of a given commercial transaction.

In addition, most consumer injuries are too small to warrant seeking legal redress. For example, imagine consumers mistreated by a merchant in transactions involving no more than a few hundred dollars each. Even if the consumers were to be commercially sophisticated enough to know they have been injured and to know that the injury is legally remediable, the damages suffered by those consumers likely would be inadequate to justify taking any legal action on an individual basis. Absent laws providing for special remedies or procedural devices to facilitate legal actions, repeat-playing merchants may be underdeterred from violating the rights of such consumers. ${ }^{86}$ This is the type of situation that has led to calls to make special legal tools available to consumers, such as class actions, attorney's fees provisions, statutory damages, and so on. ${ }^{87}$

The consumer commercial ecosystem presents unique risks for merchants, as well. Merchants' reputations are frequently at stake in consumer transactions. They can suffer severe damage as a result of just one wellpublicized dissatisfaction with their products or service. ${ }^{88}$ Moreover, as the liability regime applied to merchants dealing with consumers reflects, the expectations for product safety are different in the consumer arena than in the realm of standard business relationships, where damages models are more predictable and risk can be more successfully distributed among both sellers and buyers. Finally, the special substantive and procedural protections for consumers mentioned above, such as class actions, fee-shifting, and statutory damages, also raise the risks for merchants.

Finally, the consumer ecosystem also presents an unusual political economy. Consumer-protective laws are likely to have a sharp impact on

85. See, e.g., Amy J. Schmitz, Consideration of "Contracting Culture" in Enforcing Arbitration Provisions, 81 ST. JOHN's L. REV. 123, 159-62 (2007) (discussing relevant differences in "contracting culture[]" in consumer context); Amy J. Schmitz, Access to Consumer Remedies in the Squeaky Wheel System, 39 PEPP. L. REV. 279, 282-83, 285-87 (2012) [hereinafter Schmitz, Access to Consumer] (contrasting "B2C," or business-to-consumer practices with "B2B," or business-to-business, practices).

86. This fact is discussed at length, and supported empirically, in Schmitz, Access to Consumer, supra note 85, at 283-84; see also Schmitz, supra note 20, at 214.

87. See Bradley, supra note 3 , at 81 n.72.

88. See, e.g., Van Loo, supra note 46, at 569-70 (citing examples of individual customer complains reaching an audience of many millions, and discussing instances where social pressures altered policies at major companies). 
the bottom line of particular merchants or industries, and, thus, may spur organized and focused opposition; whereas the benefits to consumers may be substantial but diffuse. On the other hand, some laws may seem desirable to the general public but have widespread social costs that outweigh their benefits.

These unique features of the consumer protection ecosystem have significant ramifications for law and for policy. This model is a way of approaching these problems more comprehensively. Importantly, it emphasizes that all of these unusual features involve not just legal but also social and technological factors.

Virtually all concede that it is necessary to protect consumers from some types of dealings and find ways of providing some legal remedy even when individual private litigation is unlikely to deter bad action. ${ }^{89}$ But there is little agreement on the scope or nature of that regulation. Some advocates would retain only minimal regulation of egregious, often fraudulent, activity. They argue that any gains to consumers from more regulation would be outweighed by slowed economic growth resulting from inhibited behavior. In this view, regulation intended to protect consumers often drives them away from transactions that would improve their and society's welfare. ${ }^{90}$ By contrast, advocates for more consumer protection-largely, for the last couple of decades, under the influence of behavioral economics - emphasize ways in which classical rational-actor economics fails to describe actual consumer behavior. ${ }^{91}$ These voices have dominated the legal academic literature on consumer issues. A large body of scholarship has advanced arguments concerning the inadequacy of traditional common law protections and remedies, particularly those sounding in contract, for consumer commerce. ${ }^{92}$ This Article doesn't resolve this

89. See, e.g., Henry N. Butler \& Jason S. Johnston, Reforming State Consumer Protection Liability: An Economic Approach, 2010 COLUM. BUS. L. REV. 1, 8 (2010) (arguing that consumer protection statutes overdeter, but acknowledging the need for some enhanced protections for consumer transactions).

90. See, e.g., Todd J. Zywicki \& Joseph D. Adamson, The Law \& Economics of Subprime Lending, 80 U. COLO. L. REV. 1, 6-11 (2008) (discussing the benefits of deregulation of housing market).

91. See, e.g., BAR-GILL, supra note 19, at 24-25 (applying behavior insights concerning limitations of rational-actor theory to the context of consumer commercial transactions); DONALD C. Langevoort, SElling Hope, Selling Risk: Corporations, Wall Street, and the Dilemmas OF INVESTOR PROTECTION 10-13 (2016) (summarizing behavioral economics principles that have been applied to financial regulation). Consumer advocates have traditionally been skeptical of costbenefit analysis, although some proposals have been made to incorporate it more explicitly, in a way that is tailored to the distinct context of consumer protection. See Jeff Sovern, Can Cost-Benefit Analysis Help Consumer Protection Laws? Or at Least Benefit Analysis?, 4 U.C. IRVINE L. REV. 1241, 1242 (2014) (cautiously endorsing a modified cost-benefit analysis of proposed consumer-protective regulations); $i d$. at 1242-43 (explaining general reluctance of consumer advocates to endorse costbenefit analysis).

92. See, e.g., Jean Braucher, The Repo Code: A Study of Adjustment to Uncertainty in Commercial Law, 75 WASH. U. L.Q. 549, 550-52 (1997); Gail Hillebrand, The Uniform Commercial Code Drafting Process: Will Articles 2, $2 b$ And 9 Be Fair To Consumers?, 75 WASH. U. L.Q. 69, 124-27 (1997). 
debate but tries to establish a common framework for debate of particular policy questions.

The very term consumer protection plays a problematic role in policy debates. Plainly, "consumer law" is too narrow a term for the subject of this model, which goes beyond mere legal constraint. "Consumer protection" is an improvement in some ways because it signals a concern for the social, economic, and technological context of commercial relationships. But it too has a weakness: it is provocative and loaded. ${ }^{93}$ "Consumer protection" might seem to locate agency solely in merchants. It might seem paternalistic to cast all consumers as vulnerable parties in need of protection. In addition, the term focuses solely on the aspect of regulation intended to protect consumers, but regulations may have other salient or even primary goals - for instance, distributive concerns as between different groups of consumers.

But "consumer protection" remains the dominant term used in public policy discourse, and it is useful in certain respects because the primary thrust of this field is to consider ways in which consumers are different from other commercial actors - usually because they need more protection. My preference is to discuss only "the ecosystem of consumer commercial relationships," because this captures, with a more neutral tone, the scope of the key policy questions. But the phrase hardly rolls off the tongue, and there are no other ready substitutes. So, for the time being, I have recourse to the term consumer protection because it still appears to be the best available, serviceable - if flawed - term for indicating the general subject matter of this model and of this Article.

Having explained the premises and basic justification for the model in this Part, the next Part of this Article turns to the ramifications of the model for policymaking, focusing on the interrelated issues of how constraints relate to one another, and how they change over time.

\section{II.RAMIFICATIONS}

\section{A. Interdependence of Constraints}

By this point in the Article, its single most important ramification should be clear: consumer law cannot be considered without a thorough awareness of the other constraints that effectively govern consumer commercial relationships. This model reveals the interdependence of legal and other forms of constraint on consumer commercial interactions.

93. Professor-now Representative - Porter notes that she avoids this term because the subject is important to others than traditionally conceived "consumer advocates." For instance, many law students take consumer law courses because they anticipate working for corporate compliance departments. See generally KATHERINE M. PORTER, MODERN CONSUMER LAW (2016). As noted already, the model in this Article is intended to be applicable broadly and not simply as a device in favor of traditional "consumer protection" notions. See supra note 17 and accompanying text. 
In light of this interdependence, the question is which constraints should be preferred to accomplish a particular policy goal. Advocates and policymakers should consider nonlegal interventions as important levers of policy.$^{94}$ It makes sense to look beyond legal means of constraining undesirable actions on consumer commerce - or expanding the possibilities for desirable ones. ${ }^{95}$ This Article takes as a given that some constraints are desirable to accomplish policy goals in the consumer context. But this model applies regardless of whether one prefers a minimalist policy approach or a more interventionist one.

The benefits and drawbacks of different policy levers may depend on the type of challenge presented. For instance, saddling merchants with disclosure requirements, ${ }^{96}$ and making them face the risk of reputational damage as a result of what is disclosed, may sometimes suffice to accomplish a policy goal. ${ }^{97}$ Sometimes, outright prohibition of a given practice may be justified. ${ }^{98}$ At other points, prohibition would be overkill, and policymakers may choose to rely on public advocacy or technological tools to accomplish a particular goal. ${ }^{99}$

Importantly, this model suggests that consumer policy goals could be promoted by the development and promotion of technological tools. ${ }^{100} \mathrm{In}$ addition to examples already mentioned, such as pop-up blockers and advocacy efforts on social media, ${ }^{101}$ advocates have floated numerous other ideas, including retro "technologies" such as postal banking ${ }^{102}$ and better consumer-oriented dispute resolution tools, ${ }^{103}$ as well as cutting edge technologies such as artificially intelligent "customer software agents." 104 Another example is encrypted browsers such as Tor, which are powerful tools

94. On "policy levers," see, e.g., Surden, supra note 15, at 200-01.

95. As noted below, this is particularly true in times of rapid technological change, when the pace of legal change may lag far behind behavior on the ground.

96. For instance, disclosures concerning a lender's customer base or operations could be helpful: What is the average indebtedness (or ratio of average indebtedness to income) of a lender's customers? What is the average default rate? How many first loans are ultimately rolled over into second loans without the balance being reduced?

97. See, e.g., Abby Stemler, Regulation 2.0: The Marriage of New Governance and Lex Informatica, 19 VAND. J. ENT. \& TECH. L. 87, 129-31 (2016) (discussing "auditing and enforcing performance standards," and the promises and perils of reputation-based regulatory efforts). Note that this is a different sort of disclosure from that traditionally required by consumer laws, which focuses on disclosures to consumers, and has been widely criticized, although it is still thought to serve an important role. See generally OMri BEN-SHAHAR \& CARL E. SchneIDER, MORE THAN You WANTED TO KNOW: THE FAILURE OF MANDATED Disclosure (2014); Lauren E. Willis, Decisionmaking and the Limits of Disclosure: The Problem of Predatory Lending: Price, 65 MD. L. REV. 707, 712 (2006).

98. For instance, scholars have identified certain mortgage lending practices that they believe are "unsuitable per se." Engel \& McCoy, supra note 27, at 1344-45.

99. See id. (identifying practices that are "problematic" but not "unsuitable per se").

100. I have elsewhere discussed the purposes and possibilities for these tools under the term “public interest innovation." See Bradley, supra note 3, at 89-92.

101. See supra note 84 and accompanying text; see also supra note 54 and accompanying text.

102. See Mehrsa BARAdARAn, How THE Other HALF BANKS (2015).

103. See, e.g., Amy Schmitz \& Colin Rule, The New Handshake: Where We Are Now, 2 INT'L J. ONLINE DISPUTE RES. 84, 97-98 (2016).

104. See BAR-GILL, supra note 19, at 4-5 (suggesting making cell phone use data available to consumers to aid in selecting optimal service plans); Fairfield, supra note 50; Rory Van Loo, Rise of the Digital Regulator, 66 DUKE L.J. 1267, 1323 (2017) (advocating similar tools). 
to prevent not only government but also business surveillance of Internet users. ${ }^{105}$

The development of pro-consumer tools may initiate an arms race, because merchants may respond in kind. For instance, to prevent consumers' ability to price compare, merchants have labeled essentially identical items differently. ${ }^{106}$ But the effort to develop tools may be worthwhile despite the risk of such responses. Crowd-funded "start-ups" might effectively develop useful technologies, creating potential solutions for problems that other constraints have been ineffective at solving. ${ }^{107}$ Or tools could be developed by public institutions such as the Federal Trade Commission ${ }^{108}$ and the Consumer Financial Protection Bureau, whose database of consumer complaints has proven to be a useful technological tool for promoting consumer protection - and spurring legal action. ${ }^{109}$ Tools could be produced by for-profit, charitable, or educational entities interested in consumer issues. ${ }^{110}$ Even mainstream, reputationally sensitive industry players might seek to "protect" the market from "predatory" actors, while also protecting their own market share along the way.

Scholars have also proposed hybrid forms of technologically driven regulation that would deploy sophisticated information-gathering tools to yield more precise governance of consumer transactions. For instance, one ambitious but promising proposal is to require firms engaging in complex consumer transactions to draft disclosures that ensure actual consumer un-

105. See, e.g., VikTor MAYER-Schonberger \& KenNeth Cukier, Big Data: A ReVolution That Will TRANSForm How We LiVe, WORK, AND ThinK 175 (2013) ("In addition to a regulatory shift ... we envision technical innovation to help protect privacy in certain instances."). They propose regulatory requirements involving disclosure of data sources and algorithms.

106. PETERSON, supra note 18, at 242-43 ("Despite the revolution in information technology over the past twenty years, comparatively vulnerable high-cost debtors have not improved their ability to price-shop, [or] organize preferences ..."); Van Loo, supra note 45, at 1345.

107. Professor Fairfield argues: "Companies have little incentive to build tools for consumers that would prevent companies themselves from accessing potentially valuable data. That task needs to be handled by hackers, coding groups, consumer advocate groups, and private companies that want to move into building a market for pro-consumer technologies." JOSHUA A.T. FAIRFIELD, OWNED: Property, PRiVACy, AND the NeW Digital Serfdom 224 (2017); see also O'NeIL, supra note 38, at 118 ("[M]athematical models can sift through data to locate people who are likely to face great challenges, whether from crime, poverty, or education. It's up to society whether to use that intelligence to reject and punish them - or to reach out to them with the resources they need. We can use the scale and efficiency that make WMDs ['Weapons of Math Destruction,' i.e., the tools of Big Data] so pernicious in order to help people. It all depends on the objective we choose.").

108. E.g., Van Loo, supra note 45, at 1385-86 (proposing the FTC develop a program to gather data and implement a supervision program of retailers' practices).

109. Several rich scholarly works have explored the database. See, e.g., Pamela Foohey, Calling on the CFPB for Help: Telling Stories and Consumer Protection, 80 L. \& CONTEMP. PROBS. 177, 177 (2017); Angela Littwin, Why Process Complaints? Then and Now, 87 TEMP. L. REV. 895, 895 (2015); Katherine Porter, The Complaint Conundrum: Thoughts on the CFPB's Complaint Mechanism, 7 BROOK. J. CORP. FIN. \& COM. L. 57, 57 (2012).

110. Richard Hynes \& Eric A. Posner, The Law and Economics of Consumer Finance, 4 AM. L. \& ECON. REV. 168, 173 (2002) (mentioning some such tools); see also O'NEIL, supra note 38, at 144 (describing efforts at Princeton, Carnegie Mellon, and MIT to study crowdsourcing campaigns and biases in hiring). 
derstanding of the proposed terms - and submit to spot-testing to demonstrate compliance. ${ }^{111}$ All such innovations are worth considering alongside traditional law and regulation, and this Article's model supports that sort of regulatory experimentation.

Some efforts might seek to affect both technological constraints and social ones. One approach for consumer advocates would be to look to technologies that promote collective action and broad participation in policymaking, such as social media networks - to help consumers help themselves. ${ }^{112}$ Advocacy to form or change public opinion is a tried-and-true strategy and, in this particular arena, has long taken the shape of trying to deter behavior by "naming and shaming" market participants for acts that are not socially acceptable. ${ }^{113}$ Social media platforms have given consumers a new tool for raising concerns with companies - and coordinating with one another to do so. ${ }^{114}$ These tools facilitate collection of data, development of ideas, and coordination of efforts. ${ }^{115}$ They can provide means of political organizing and permit highly motivated individuals, who might otherwise have been too remote, to link together and form policy coalitions. ${ }^{116}$

The capacity of technology to lower the costs of consumer coordination speaks directly to a key rationale for consumer protection: the comparative weakness of individual consumers engaging in one-off transactions with repeat-playing merchants. This is an area in which consumerfavoring technology, whether produced by for-profit firms or in a public interest context, holds considerable promise, potentially increasing the power of technical and social constraints on merchants. ${ }^{117}$ Again, the interdependence of the different constraints in this model is clear because improved advocacy networks could affect both legal and social constraints.

111. See Willis, supra note 83, at 1315 ("Performance-based consumer law together with ongoing field-testing has the potential to incentivize firms to educate rather than obfuscate, to develop simple and intuitive product designs that align with, rather than defy, consumer expectations, and to channel consumers toward products that are suitable for consumers' circumstances.").

112. See Arbel, supra note 19 (suggesting mechanisms for improving reputational constraints on businesses in consumer interactions).

113. There are many well-known examples, including RALPH NADER, UNSAFE AT ANY SPEED: THE DESIGNED-IN DANGERS OF THE AMERICAN AUTOMOBILE 18-23 (1965) (describing car manufacturers' neglect of, and disdain for, effective safety measures in cars); UPTON SINCLAIR, THE JUNGLE 12 (1906) (describing conditions and practices of meat-packing industry and leading to broad industry reforms both voluntary and legally imposed).

114. Jonathan Wolfe, Want Faster Airline Customer Service? Try Tweeting, N.Y. TIMES (Nov. 20, 2018), https://www.nytimes.com/2018/11/20/travel/airline-customer-service-twitter.html.

115. Vindu Goel, G.M. Uses Social Media to Manage Customers and Its Reputation, N.Y. TIMES (Mar. 23, 2014), https://www.nytimes.com/2014/03/24/business/after-huge-recall-gm-speaks-to-customers-through-social-media.html.

116. See, e.g., Clive Thompson, Social Networks Must Face Up to Their Political Impact, WIRED (Jan. 5, 2017, 6:01 PM), https://www.wired.com/2017/01/social-networks-must-face-political-impact/.

117. See supra notes $114-115$ and accompanying text. 


\section{B. Constraints Over Time}

The three broad types of constraint that form the basis of this model are interconnected in a second way: a change in any one of them will affect the others. This model reveals the importance of evaluating changes in the various constraints as technology develops, laws are enacted or repealed, and social attitudes change.

Often, a change in one constraint will expand or contract the set of permitted actions, which may encourage the easing or tightening of other constraints. One example would include a merchant who gains some tricky, new technological advantage, which over time, after being filtered through public deliberation and the legislative process, is then condemned or constricted through social norms or legal regulation. Other examples might be how social networking has changed social norms on privacy and how electronic signatures and mobile banking have changed views on traditional transactional formalities. ${ }^{118}$ The influence can also run the other direction: technology takes cues from society and culture; technology businesses focus tremendous energy on trying to give consumers what they want. ${ }^{119}$ Similarly, views on the social acceptability of particular conduct can lead to legal change ${ }^{120}$ _or alternatively, views themselves can be shaped by what has been deemed unlawful. ${ }^{121}$

The point is that the system is highly dynamic and multilayered, and any change may set off a complex, iterative process in which various factors react to one another. This interdependence is a crucial aspect of policy change in this arena. Figures 4 and 5 illustrate this.

118. See Schmitz, supra note 20, at 247; Smith \& Anderson, supra note 20.

119. Although Steve Jobs famously claimed that "customers don't know what they want until we've shown them," this is of course not the usual method for product development in successful technology businesses. WALTER ISAACSON, STEVE JOBS 143 (2011).

120. There is a vast literature on how, and for whose benefit, such change happens. See, e.g., Anne N. Costain \& Steven Majstorovic, Congress, Social Movements and Public Opinion: Multiple Origins of Women's Rights Legislation, 47 POL. RES. Q. 111, 111 (1994).

121. See, e.g., ELLICKSON, supra note 15, at 75 (reflecting on whether the law influenced social norms regarding responsibilities for fence-building expenses among neighboring landowners in Shasta County, or whether the norms shaped the legal regime); $i d$. at 284 (noting that "legal policies themselves influence the vitality of informal systems of social control [i.e., norms]"). 


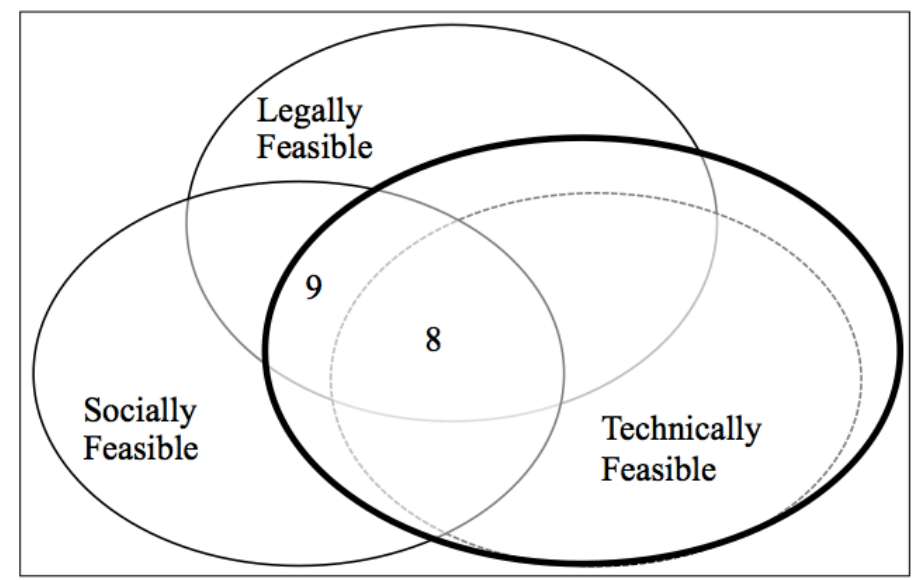

Figure 4.

Figures 1-3 took place at one moment in time $(t 1)$, and the scope of permitted actions was the Area 8 . Figure 4 advances to a later moment in time, $t 2$, when more actions have become feasible due to technological advancements. Note that all of the areas in the previous figures have been altered by the change in technology. Most importantly, the scope of permitted actions is larger, as indicated by the addition of Area 9 to Area 8 .

$P A t 2=8+9$.

Note that the scope of the law has not changed. Nonetheless, the terrain of legally permitted actions, and permitted actions generally, is significantly larger. In other words, there has been an expansion of the actions that market participants are effectively permitted to take. Stated differently, the scope of consumer protection has been eroded by the amount of this expansion. ${ }^{122}$

The changes represented in Figure 4 are not normatively good or bad on their face. But they are relevant for consumer policy going forward after time $t 2$. A change might be used, for example, to supply a regulatory rationale - to argue that policies should be updated to deal with concerns raised by newly feasible practices. Alternatively, the change could support an argument that a regulation is no longer necessary because of a cheaper or more tailored technical "fix" now available. Perhaps technological tools, such as those now referred to under the umbrella term Big Data, could be deployed to anticipate social or technological developments that will render existing regulation obsolete or counterproductive. Such tools would permit predictive regulation or deregulation, thus eliminating some

122. My use of "erosion" in this context is indebted to Professor Harry Surden. In his important work developing similar principles (largely focused on intellectual property), Professor Surden articulates the effects of such changes: "[T] he Technological Cost of activities can change over time. Emerging technologies frequently eliminate the capacity-limiting constraints common in the previous technological era. When legal frameworks depend upon activities being Technologically Costly, they are susceptible to shifts in strength, scope, or effectiveness when the Technological Cost of activities decreases." See Surden, supra note 15, at 138-39; id. at 142 (referring to this process as a technological erosion of legal rights). 
of the "lag" that bedevils regulation in quickly developing policy areas. This is the hope of some who have begun to advocate for "smarter," more technologically adept regulatory strategies. ${ }^{123}$

Importantly, this model underscores that many nominally "legal" practices aren't feasible at any given time. And, if they aren't feasible, they almost certainly aren't considered by prior policymakers. Accordingly, there is a sound rationale for new attention (whether regulatory or deregulatory in normative direction) to be focused on the newly emerging technical possibilities. This is a crucial insight yielded by the model-although, as already stated, this model does not directly address the policy steps that should be taken.

In Figure 5, we can consider the effect of a change in the law, at a third time: $t 3$. Here, Area 10 is the new scope of permitted actions: PAt3 $=10$. Area 11 indicates what used to be permitted at $t 2$ but is now unlawful - it has been removed from the scope of previously permitted actions.

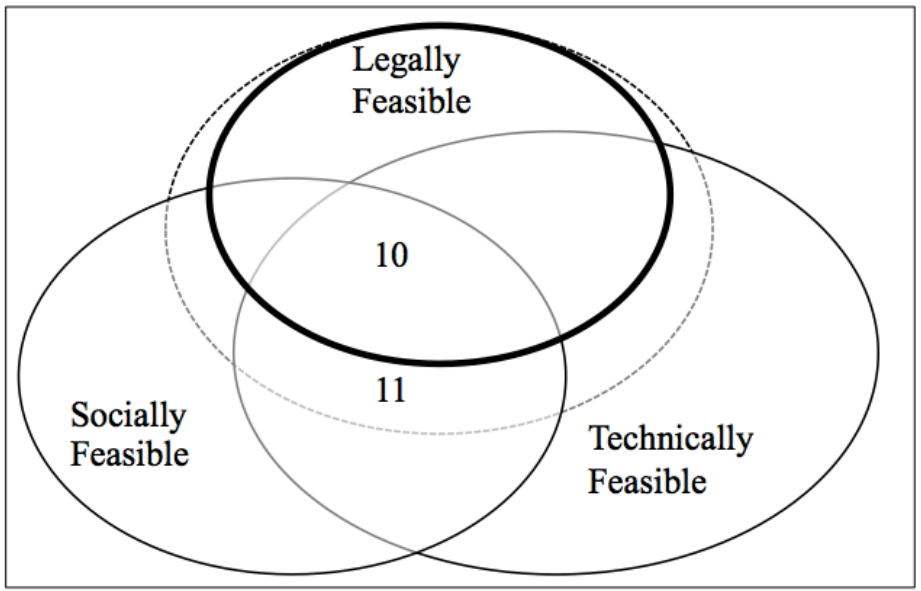

Figure 5.

The law has changed from time $t 2$ to $t 3$; there has been a constriction of the scope of permitted actions. Because of technological advancement, previously infeasible conduct may become easier and, thus, more common. In response- assuming that the goal is to preserve the pre-existing baseline or the regulatory balance ${ }^{124}$ - legal tools may be deployed, as depicted in Figure 5. One of the other areas could also be contracted: social

123. See Engel \& McCoy, supra note 27 and accompanying text.

124. As with other areas of regulatory law or policy (for instance, environmental law or privacy law), there is presumably a socially desirable amount of regulation at any given time, although what amount that is, and what factors should be weighed to determine it, are contestable. A situation that yields either more or less regulation than that optimum amount is socially undesirable. There is of course no reason to believe that at a particular time we enjoy the optimum amount of regulation in any area, although it might seem reasonable to take the current level as a baseline against which to examine future effects-leaving to the side whether those effects either bring the existing regime closer to alignment with an optimum regulatory arrangement or further take it out of alignment, which will be determined by normative views concerning the baseline state of affairs and not dictated by this model. 
norms could constrain the newly possible conduct, or technological tools could be developed by public authorities or by advocates to narrow the scope of permitted actions.

Thus, while there may be many differences in the way legal and technical constraints are thought about or acted upon, they work in tandem and may be substitutable for one another in the context of the effective scope of consumer protection at any given time. ${ }^{125}$ And consumer commercial relationships will be particularly dynamic when any of the categories of constraints are rapidly changing. Therefore, policy analyses will have to be equally dynamic.

The two ramifications that have been surveyed in this Part of the Article suggest that the scope of consumer policy and the stability of the regulatory framework depend on the social and technological context, which may be highly dynamic, requiring frequent adjustments at times of social and technological change. The area of permitted action at the center of the Venn diagram will quickly change as new types of socially and technically feasible activities emerge. Reacting to such changes poses particular challenges and should encourage policymakers to consider, for instance, what types of institutions and policy approaches are best, not just in the current context but in anticipation of future changes. This is the subject of the next Section, which focuses on the ramifications of rapid technological change as conceived in this Article's consumer protection model.

\section{Implications of Technological Change for Consumer Policy}

Technological change deserves particular consideration. As this model reveals in Figure 4 above, protective regulation takes place against the factual background existing at a given time. Progress in technology makes existing regulation outdated or ill-fitting in various ways with respect to each new reality that technology presents to market participants. Consumer commerce has been, and continues to be, shaped by dramatic new technology developments as a result of the rise of mobile computing and Big Data. ${ }^{126}$ Technological changes tend to initiate an iterative and unstable process that requires multiple interventions simply to maintain a semblance of the pre-existing baseline of regulation - to preserve what could be conceived of as the "regulatory balance" between the different interests implicated in consumer transactions.

To be clear, the model also emphasizes that interventions need not be legal in nature-we need not trust in law alone. Policy interventions could

125. On the relevant work of Professors Lessig, Ellickson, and Surden, whose ideas have greatly influenced this project. See supra note 15 and accompanying text.

126. As some technologists have put it, only somewhat hyperbolically: "We are in the midst of a great infrastructure project that in some ways rivals those of the past, from Roman aquaducts to the Enlightenment's Encyclopedie. We fail to appreciate this because today's project is so new, because we are in the middle of it, and because . . . the product of our labors is intangible. The project is datafication. Like those other infrastructural advances, it will bring about fundamental changes to society." MAYER-SCHONBERGER \& CUKIER, supra note 105, at 96. 
include countervailing technological developments or changes in social norms. These practical constraints can have the effect of shifting the protective frontier in one direction or another, or of moving in the direction of restoring the balance of interests. None of this points to any particular answer to the important normative question of whether this "balance" is appropriate in the first place - in other words, whether there is too much or too little consumer protection in the baseline state. But this model provides a sound structure for approaching that question from a better-contextualized starting point.

Technological changes can unsettle an existing legal regime when they enable a party to take actions that were previously unavailable or that have become much easier. Such technological changes may shift a regulatory balance in one direction or the other, potentially undermining whatever policy rationale justified that regulatory status quo in the first place. To take a prominent example from constitutional law, consider the development of infrared search technology that permits police to "search" a house from outside on the street. When the Supreme Court grappled with this issue in Kyllo v. United States, ${ }^{127}$ it had to determine whether its old legal rule, which was that searches undertaken in a public place (the street) were presumptively permitted, still applied when the search tool (infrared camera) was much more invasive than previous technology. The tool had the effect of shifting the balance in the favor of the searchers over the searched. The legal rule had to shift to restrike the balance. In Kyllo, because the legal test involves reasonable expectations of privacy, social norms were involved as well. ${ }^{128}$

In consumer law, technological developments around privacy and personal data furnish a similar example. Consumer data can be put to uses inconceivable when it was gathered, and users of the data explore new uses every day. Models of protection of privacy that rely on consent cannot make sense of such a world. Depending on how strictly consent is interpreted, productive and benign uses may be ruled out, or consumers may suffer the consequences of aggressive, unanticipated uses of their personal information. ${ }^{129}$

Interventions may be required more often under some conditions than others - namely, (1) if technology is evolving quickly and (2) if it is doing so in such a way as to significantly shift a regulatory balance. Both stated conditions are necessary: if technological change is slow, then new interventions may correspondingly be required only rarely; if technological change isn't likely to shift a regulatory balance, but, instead, is merely lowering transaction costs for all, then there is no need for intervention. It

127. 533 U.S. $27,28-29(2001)$.

128. Id. at 33-34.

129. See MAYER-SCHONBERGER \& CUKIER, supra note 105, at 173 (noting inadequacy of consent-based models "[i]n the era of big data ... when much of data's value is in secondary uses that may have been unimagined when the data was collected"). 
may be the case that when technological change proceeds slowly, it is easier for society to identify its effects and craft policy to deal with them. In contrast, more rapid changes may outstrip society's capacity for deliberation. ${ }^{130}$ In addition, regulatory capture may mean that it is difficult or impossible to regulate due to the dispersed benefit of additional regulation and the concentrated benefit (by the industry) of failure to regulate. ${ }^{131}$

There is substantial academic literature occupied with the fact that technological change often outpaces that of legal change. ${ }^{132}$ One lesson from that body of research, which is consistent with this Article's model, is that the appropriate type of legal intervention should be influenced by the anticipated pace of change as well as the expertise required to identify and consider legal response to those changes. For instance, expert institutions empowered to enforce flexible, standards-based laws and regulations may be preferable when rapid adjustments are expected. ${ }^{133}$ On the other hand, where the market environment is relatively stable, the greater certainty and enforceability of bright-line rules may be preferable.

In the consumer protection context, the iterative process of technological change and intervention has important implications for how consumer protection laws should be crafted as well as for how institutions should be established or empowered to monitor and enforce legal compliance in the face of technological change. There are other relevant factors to be weighed, such as the degree of political accountability and the level of government most appropriate for a given legal response.

The rigidity of some forms of legal response may be undesirable because technology can have complex policy effects (for instance, having alternately consumer- or merchant-favoring aspects), and because new technologies typically build in unanticipated ways on prior innovations.

130. The process by which social norms are developed requires at a minimum sufficient time to pass, and public attention to be directed to the issue, such that society can become aware of the issue and then come to views about its acceptability. See generally O'NEIL, supra note 38, at 144-60 (discussing and collecting sources on the process by which social views make their way into law).

131. See generally ELLICKSON, supra note 15, at 257 ("Government rulemaking is particularly unlikely to be welfare enhancing ... in the many spheres of activity in which well-placed rent seekers can obtain legislation that aids them at the greater expense of the politically weak."); MANCUR OLSON, The Logic of Collective Action: Public GoOdS AND the TheORY OF Groups 1-3 (1965) (describing, inter alia, the greater responsiveness of legislative actors to focused interests over the broader public that faces only diffuse harms or benefits from any particular legislative intervention).

132. This fact is especially evident in the burgeoning body of scholarship trying to bring technological innovation into the regulatory space. See, e.g., Douglas W. Arner et al., FinTech, RegTech and the Reconceptualization of Financial Regulation, 37 Nw. J. INT'L L. \& BuS. 371, 371 (2017); Chris Brummer, Disruptive Technology and Securities Regulation, 84 FORDHAM L. REV. 977, 1035-39 (2015); Wulf A. Kaal and Erik P.M. Vermeulen, How to Regulate Disruptive Innovation - From Facts to Data, 57 Jurimetrics (forthcoming); Rory Van Loo, Regulatory Monitors: Policing Firms in the Compliance Era, 119 COLUM. L. REV. 369, 404-08 (2019); Willis, supra note 83, at 1322-23 (proposing the use of novel testing requirements to ensure effective disclosure of important but often overlooked or misunderstood transactional terms); Willis, supra note 54, at 126-27 (noting that tech firms can rapidly try out different tacks to see what is effective but that "[p]olicymakers are not nearly so agile").

133. See, e.g., Van Loo, supra note 132, at 397-98. 
Rigid or blanket prohibitions may have the effect of obstructing or foreclosing innovations that might prove beneficial — and might even render regulation unnecessary. One way of preserving oversight alongside flexibility is to create "regulatory sandboxes," zones of permitted experimentation and regulatory forbearance for technology businesses in select arenas. $^{134}$

In addition to law being a slow-moving tool, and to it being vulnerable to capture, there is also the problem that it is unlikely to be as forwardlooking as technologists themselves are. It is difficult to regulate things that we can barely dream up. Lawmakers are understandably reluctant to be too forward-looking in regulations - to regulate hypotheticals. Regulating such "bleeding-edge" technologies rarely will seem a worthwhile use of legislative resources or political capital. And, even if political will is present, it requires an accurate anticipation of what emerging technology will look like and how society and businesses will respond to its introduction.

As recently as a decade and a half ago, "going viral on social media" was a phrase that would mean little. Thus, we could hardly have expected regulation regarding privacy or property rights in "viral videos," any more than we could have expected regulation of the flying skateboards that Back to the Future Part II predicted would be commonplace by 2015 (but that we, unfortunately, still await). ${ }^{135}$ To take another example, a futuristic technology that beat flying skateboards to store shelves is that of a "starter interrupter" or "kill switch" device, which has dramatically changed the car repossession industry (and, thus, the car lending arena, particularly for "sub-prime" borrowers). ${ }^{136}$ Generally speaking, these are devices placed on vehicles by lenders who, if the owner of the vehicle defaults on loan payments, can activate the device to get its precise location, and disable the car's engine. The technologies required to produce such a device at reasonable cost were only developed recently. Therefore, it is understandable that no particular laws were in place governing their use. Although the general backdrop of common law and statutory consumer law protections were in place providing some backstop against abuses, these protections may be insufficient. ${ }^{137}$ Regulators in some states have scrambled to investigate this technology and promulgate rules governing the way such devices can be used-for instance, to ensure that cars are in safe places,

134. See Bradley, supra note 50, at 85-89 (discussing regulatory sandboxes).

135. BACK TO THE FUTURE II (Universal Pictures 1989). The wheeled "hoverboards" that have become popular of late are fun to ride, but still do not approach the allure of a true flying skateboard.

136. See Bradley, supra note 3, at 78; Michael Corkery \& Jessica Silver-Greenberg, Miss a Payment? Good Luck Moving That Car, N.Y. TiMES (Sept. 24, 2014, 9:33 PM), https://dealbook.nytimes.com/2014/09/24/miss-a-payment-good-luck-moving-that-car/.

137. Juliet M. Moringiello, Electronic Issues in Secured Financing, in RESEARCH HANDBOOK ON Electronic COMMERCE LAW 285, 297-303 (John A. Rothchild ed., 2016) (surveying and critiquing current commercial law implications of this type of device); Erica N. Sweeting, Comment, Disabling Disabling Devices: Adopting Parameters for Addressing a Predatory Auto-Lending Technique on Subprime Borrowers, 59 How. L.J. 817, 818-19 (2016) (arguing for stricter regulations of such devices). 
that debtors are given advance warning, and so on. ${ }^{138}$ But such efforts, by necessity, lag the innovations themselves. Figuring out the degree to which legal or social constraints should fill the space left by these technological advances is the core of the challenge (as visually depicted in Figure 4 above).

Online lending is another recently ascendant consumer transacting technology that presents significant policy concerns. Online lenders, like many other participants in the consumer finance industry, have benefitted from technological innovations, including from what is perhaps euphemistically referred to as the "lowering of compliance costs."139 But the lowering of compliance costs is not an unqualified good. It has at least two pertinent dimensions, both of which are in evidence in online lending. One function that technology can have is to lower the cost of compliance with existing laws and regulations. Required reports and notices can be automatically generated; charges can be accurately counted and provided at a moment's notice; entire swathes of "back office" functions can be automated. This lowering of transaction costs has likely yielded significant net benefits for society. ${ }^{140}$ By contrast, compliance costs can be saved by the evasion of legitimately imposed and normatively desirable protections. This can occur, for instance, by exploiting technology to perform an otherwise prohibited act - essentially as a form of technologically enabled regulatory arbitrage. ${ }^{141}$ Some online lenders, particularly those unaffiliated with major financial institutions, seem to be profiting, at least in part, from these unsavory practices. This is an apt example of an area where regulation understandably lagged as the industry, and the technology upon which it relies, developed rapidly. Regulatory energy can and should be focused on distinguishing between technologically driven reduction of compliance costs and technologically enabling evasion of compliance itself.

As I have argued in prior work on financial technology, ${ }^{142}$ many technologies have a double edge because they provide inarguable societal benefits yet also raise consumer protection concerns. In fact, many consumer advocates seem to believe that consumers have lost significant ground and

138. See Moringiello, supra note 137, at 297-303; Sweeting, supra note 137, at 833-34.

139. See Christopher K. Odinet, Consumer Bitcredit and Fintech Lending, 69 ALA. L. REV. 781, 803-04 (2018).

140. Of course, it may have problematic distributive effects, for instance on former back-office workers whose skills are no longer in demand. But while these distributive effects may merit a policy response, the overall benefits appear likely to have been substantial and a rational response would be unlikely to involve clawing back use of these innovations.

141. There is an important and still developing scholarship on this point as regards the "gig economy." See Benjamin G. Edelman \& Damien Geradin, Efficiencies and Regulatory Shortcuts: How Should We Regulate Companies Like Airbnb and Uber?, 19 StAN. TECH. L. REV. 293, 327 (2016) ("Notably, when these services take regulatory shortcuts, it is difficult to know whether the services gain traction through genuine excellence and efficiency, or through regulatory arbitrage."); Pollman \& Barry, supra note 74, at 384-409; id. at 397 n.61 (distinguishing between regulatory arbitrage and the authors' term, "regulatory entrepreneurship"). There is also important scholarship on this issue in the context of online lenders. See Odinet, supra note 139.

142. Bradley, supra note 3 , at 80-82. 
are being taken advantage of now more than ever. Unfortunately, I'm not aware of any empirical work addressing this point. ${ }^{143}$

Take, for example, price comparison tools and shopping platforms. These platforms allow consumers to compare potential loan terms before they enter a car dealership or to compare insurance quotes from numerous vendors. ${ }^{144}$ But the owner of the platform may also use the consumer's information to gather detailed and monetizable consumer information profiles, to steer business in preferred directions (potentially for a finder's fee), and to price discriminate based on anticipated consumer behaviorall without the consumer's awareness. ${ }^{145}$ This isn't necessarily undesirable; overall social welfare could be increased if lenders are able to target likely customers for particular financial products, or it could be diminished if the outcome is merely to steer unsophisticated borrowers into inferior products. That is a difficult, multidimensional question requiring contextualized analysis of the practices in question. Either way, the novel business practices of such platforms implicate longstanding consumer protection policy concerns and complicate the weighing of costs and benefits.

Most of the policy tools sketched in this Article may seem to be consumer-protective in the sense that they are ways of narrowing the scope of permitted actions under the model. This is because we can expect innovations usually to expand possibilities by permitting parties to engage in behavior not previously possible - or behavior that would have been unlawful if done in the old way but may not be if done in the new way. The area of technical feasibility, in other words, seems likely to expand rather than contract, and, thus, to demand consistently renewed regulatory attention. Often, the net effect of technological change will be commerce- or merchant-favoring. Merchants are well-funded repeat players with concentrated financial stakes in attaining outcomes favorable to their interests. Merchants are likely to have greater motivation, funds, and expertise,

143. Professor Van Loo argues: "[I]n the modern technological and scale-driven commercial landscape, the sophistication gap between buyers and sellers of goods is large and has grown considerably, as it has in financial products." Van Loo, supra note 45, at 1334; see also Schmitz \& Rule, supra note 103, at 84 ("At the dawn of the internet age many futurists predicted that technology would shift the balance of power between consumers and merchants in favour of consumers.... In some respects the internet has achieved the opposite, ushering in a new age of consumer confusion and disempowerment."). Professor Zywicki provides a useful opposing view, pointing out the usefulness of various innovations, including credit products such as overdraft protections, online lending, and prepaid cards. See, e.g., Todd J. Zywicki, The Economics and Regulation of Bank Overdraft Protection, 69 WASH. \& LEE L. REV. 1141, 1144 (2012) [hereinafter Zywicki, Regulation of Bank]; Todd J. Zywicki, The Economics and Regulation of Network Branded Prepaid Cards, 65 FLA. L. REV. 1477, 1478-79 (2013) [hereinafter Zywicki, The Economics and Regulation].

144. See Bradley, supra note 3, at 63-68 (explaining LendingTree's basic business model and appeal to consumers); Van Loo, supra note 104, at 1291-93 (discussing concerns about Lending Tree and similar companies' choice architecture).

145. See, e.g., FAIRFIELD, supra note 107, at 7 ("[C]omparison shoppers pay more for airfare because their browser histories indicate they are very interested in certain flights."); Bradley, supra note 3, at 68-70 (noting "the implications of the widespread use of LendingTree's technology are mixed from a consumer perspective," and discussing aspects of the model that consumers may not be aware of and that might harm their interests); Van Loo, supra note 104, at 1267 (expressing concern that digital intermediaries "subtly advance their interests at the expense of those they serve"). 
which allow them to induce and take advantage of innovations more effectively than consumers. As in the political context, so too in the technical one: consumers' diffuse interests makes them more susceptible to coordination difficulties that leave them weaker than that of concentrated merchant interests. ${ }^{146}$ Accordingly, and despite these headwinds, most policy energy will likely have to be expended in the direction of providing greater protection.

Early optimism about the information technology revolution has been dampened considerably by the rise of large, extremely powerful, and profit-focused technology companies. The rise of Big Data, which includes the technologically enabled rise of tools to track consumer Internet behavior and the increasingly developed trade in detailed consumer data, ${ }^{147}$ at least makes clear that information technology is no social or political panacea. Difficult social, legal, and technological questions are going to continue to arise - if anything, more often now than ever.

In conclusion, there are two closely related policy implications of technological change that the consumer protection model brings to light.

First, interventions (of whatever sort) may be required more often when technology evolves particularly quickly, as has been the case in recent years. ${ }^{148}$ As this model's multifaceted and contextualized approach shows, an assessment of the effects of technological change and new business practices is more complex than it might initially appear. And, mapping the effects on this model is only the beginning of the debate about whether the developments are normatively desirable and how the developments should be dealt with as a matter of policy to provide necessary regulation without stifling innovation. The iterative and dynamic process reflected in this model should be a significant factor in selecting appropriate laws for consumer protection and shaping institutions for monitoring and enforcing compliance. ${ }^{149}$ Some approaches may be more successful than others in such a quickly changing and complex environment.

Second, because the pace of legal change may lag behind that of technological change, advocates for and against consumer protection should consider promoting their ends through means other than law. For example, they could encourage the development and promotion of technological tools that accomplish advocates' desired policy ends.

146. As noted, some technical tools may partially mitigate consumers' disadvantage in this respect. See supra notes 113-117 and accompanying text.

147. See, e.g., FAIRFIELD, supra note 107, at 6.

148. See, e.g., Bradley, supra note 3, at 82-92 (discussing ways to approach the regulation of quickly evolving financial technology businesses).

149. Professor Van Loo has identified and explained the importance of the rise of "regulatory monitors," who often perform regulatory functions by using tools other than those of traditional enforcement. See generally Van Loo, supra note 132, at 371-72. Some of the activities of such monitors might be classified as "legal constraints," while others (e.g., "public shaming") should be seen as social constraints. Still others (e.g., requiring the provision of technical data and operational information) might function effectively as technical constraints. 
The next Part turns to potential objections to this model as presented so far, and proposes some refinements that will help as this model is applied to particular sets of circumstances.

\section{REFINEMENTS}

This Part answers several potential objections and suggests directions in which the model could be developed further.

\section{A. Varieties of Consumers, Merchants, and Commercial Relationships}

One potential critique of this model is that legal, social, and technical factors will constrain some market participants more or less than others. Consumers, merchants, and the transactional relationships they pursue are all different in meaningful ways, which may not be reflected in this Article's model.

Compare an online lender, thinly capitalized, based overseas, and established the month before a transaction, which may have little risk of legal sanction or concern for reputational cost, with an established institution with a "brick-and-mortar" presence in its customers' community. ${ }^{150}$ The latter's submission to social norms, to legal jurisdiction, and to regulatory compliance norms is much more likely. By contrast, ephemeral corporate entities - described above as "disposable" entities - might require different and tighter constraints. ${ }^{151}$ Modeling the constraints on merchants in general might not capture important variations among the range of actors.

The same principle applies to consumers. Modeling the degree to which consumers in general are "protected" may not capture important data concerning variations among the consumer population. Consider a consumer from a vulnerable class, who may be more in need of protection than the bulk of individuals who are able to navigate certain types of transaction with little to no protection. ${ }^{152}$ The need for consideration of all of these distinctions, which applies to any analysis of commercial relationships, is especially salient in the consumer context, because many of the justifications for consumer law emerge directly from beliefs about the vulnerabilities of particular groups or the advantages (the "uneven playing field") enjoyed by their commercial counterparts. A policy intervention may hurt some consumers despite helping others. ${ }^{153}$ Other interventions may be challenging to implement for a similar reason: efforts at consumer

\footnotetext{
150. See supra notes $32-44$ and accompanying text.

151. See supra notes $43-44$ and accompanying text.

152. See, e.g., PETERSON, supra note 18, at 214-30 (discussing vulnerable groups).

153. See, e.g., Richard A. Epstein, The Neoclassical Economics of Consumer Contracts, 92 MiNN. L. REV. 803, 810 (2008) (discussing the implications of "extensive consumer heterogeneity" for consumer protection regulations, which the article generally offers arguments against).
} 
education or disclosure may be effective as to some but not all consumers, having the undesirable effect of picking winners and losers. ${ }^{154}$

Not all transactions are the same, either. Transactions involving health care have moral, legal, and financial significance beyond that of a trip to the grocery store. A home mortgage transaction requires the coordination of numerous actors, compliance with complex regulations, and the undertaking of a large financial obligation by the consumer. What successfully constrains misbehavior in one type of transaction may not do so in another (due, for instance, to different degrees of concern over social pressure), or may constrain misbehavior at one price level but not another (due, for instance, to degrees of concern over legal compliance risk).

No doubt, this model may yield a different set of permitted actions in one context than in another. It is dependent on the time, place, actors, and transactions under consideration. Responding to this concern, one way this model could be applied in particular situations is by mapping how parties in a particular type of commercial relationship might experience the relevant constraints. In other words, the characteristics of the participants (merchants as well as consumers), and the types of transaction(s) they intend to pursue, could be considered in applying this model to a policy question. Each relationship - each unique set of participants and each unique type and size of transaction - could be considered by reference to a different version of the model's diagram. This approach simply reflects the reality that each consumer relationship is governed by a different configuration of constraints. More tailored versions of this model could reflect this more nuanced aspect of reality.

This Article avoids the weighing of justifications for consumer protection. ${ }^{155}$ Nonetheless, it may be useful to consider how different laws and institutions may be more justifiable or salient to different regulatory constituencies. For example, some consumer protections are geared toward addressing distributive concerns, including laws that require bank customers to opt-in to "overdraft protection," and prescribing methods for banks applying and processing overdraft transactions and charges. ${ }^{156}$ Leaving aside the merits of these particular laws, they have little bearing on the lives of most wealthy consumers; rather, they are methods for financial institutions to wring profit from small accounts. By contrast, the seemingly unobjectionable right to have a free "credit freeze" put on credit

154. Professor Willis notes that technologies might allow merchants and regulators to distinguish among groups. See, e.g., Willis, supra note 54, at 126-27 ("Consumers are a diverse and fickle lot; what one consumer finds acceptable another finds out-of-bounds, and a single consumer might find a path-breaking firm's actions disquieting at first but unremarkable if the rest of the market moves in the same direction. However, firms can send a diverse set of marketing messages (informed by behavioral tracking data) and only need one of these to work with any particular consumer.") (footnote omitted)).

155. See, e.g., PORTER, supra note 93, at 10-12.

156. See, e.g., Zywicki, Regulation of Bank, supra note 143, at 1141 (2012) (summarizing, and criticizing, current regulatory approaches). 
reports at the major credit reporting agencies seems likely to benefit primarily the relatively sophisticated, who will understand why a freeze is a good idea, who will bother to do it, who have significant credit to protect, and who do not need to access new credit regularly because they maintain ample open lines. Further work may require that this Article's model better address the differences between protections such as these that are focused on particular groups and protections whose benefits are not so concentrated. More refined and specific models might better describe the dynamics that will be at play in specific consumer protection subareas.

A specific concern of this nature, which may become more salient as technology becomes more pervasive in daily consumer transactions, is access to technology. If it is the case that technological advancements can serve as consumer protection tools, then access to the relevant technology amounts to access to justice. For instance, tech-savvy people may be more protected from abuses by technological tools. If it were easy to confirm that a large percentage of a given group is already protected through those means, policymakers might not deem it worthwhile to help that group any further through law. The problem is an obvious one with respect to specifically legal tools, such as online dispute resolution tools, which may in effect require access not just to a reliable Internet connection but also tools for document creation, scanning, or submission, requiring a significant degree of technological access and skill.

The same concern may be present less directly, but just as importantly, with respect to tools for protecting privacy, or for coordinating consumer advocacy on social media. The capacity to deploy social media effectively is a modern skill. Knowledge of, and access to, the best technological tools for accomplishing a given consumer's goals may be beyond the capacity of some. But because access to legal tools-lawyers, legal research tools, etc.- - has long been available in only a limited fashion to many, it is far from clear that reliance on technological tools would make low-resourced individuals worse off on net. At the same time it remains important that, merely because the areas of deprivation and inequality have shifted, reliance upon technology not lead to an erroneous conclusion that access to justice issues are solved.

In addition, consumer privacy, discrimination against protected classes, and abusive contracting practices have all formed important parts of policy discussions in the consumer arena, yet they all have different etiologies and demand distinct responses. ${ }^{157}$ Some areas may be more susceptible to legal interventions than to technologically driven ones. Other areas

157. The realm of privacy is an area of consumer-facing policy where there is a very well-developed literature disaggregating a number of different concerns. See, e.g., Alessandro Acquisti, Privacy Costs and Personal Data Protection: Economic and Legal Perspectives, 24 BERKELEY TECH. L.J. 1060, 1065 (2009); Scott R. Peppet, Regulating the Internet of Things: First Steps Toward Managing Discrimination, Privacy, Security, and Consent, 93 TEX. L. REV. 85, 124-32 (2014); Surden, supra note 23 , at $1606-07$. 
of consumer protection may be more prone to undetected "creep" of technological advancement at the expense of legal protection. ${ }^{158}$ More refined versions of this model could be useful in identifying these distinctive characteristics.

In sum, this model can provide both a bird's eye view as well as more tailored, fine-grained views. This capacity is a feature, not a bug. This model can aggregate various forms of legal protection and technological capability and may obscure important distinctions among different types of consumer protection concerns. Setting an appropriate level of detail for a given application of the model requires careful judgment and may provoke debate.

A final observation here is that it is not just this model, but the underlying law and policy, that needs to become more refined to take into account differences among different actors and relationships. What this critique reveals is that a move toward bespoke consumer policy (and not just a bespoke model) needs to be considered more seriously. ${ }^{159}$ Perhaps laws and policies should be tailored to types of consumers, types of merchants, and to the types of commercial relationships entered into. ${ }^{160}$ This might represent a radical shift in some ways but might also make the most sense of a field that currently otherwise lacks coherence. This model can hopefully serve as a tool to advocate for that change.

\section{B. Consumer Self-Defense and Learning}

A second objection is of a more libertarian bent: this model relies too heavily on the paternalistic underpinnings of traditional consumer protection and ignores the degree to which consumers can and will protect themselves if it is in their interest to do so, by learning to be suspicious of dangerous actors or practices and otherwise adjusting their behavior. ${ }^{161}$ In

158. "Technology creep" is a term that has been used in various contexts to indicate the way that new technologies can accumulate over time to bring changes that seem small individually but in the aggregate are quite substantial. See, e.g., Lesley Alderman, How to Leave Work at the Office, CNN (Mar. 30, 2009), https://www.cnn.com/2009/LIVING/03/30/leave.work.at.the.office/index.html (using term with respect to manage workplace technologies and demands with personal life); Adrienne Erin, Technology Creep is Making Healthcare More Expensive, BHM HEALTHCARE SOLUTIONS, https://bhmpc.com/2014/12/technology-creep-making-healthcare-expensive/ (using term with respect to healthcare technologies and expenses).

159. This is part of what Professor Langevoort refers to as the "dilemma of investor protection." LANGEVOORT, supra note 91, at 13 (2016) ("Investor protection struggles with the many different kinds of investors in the marketplace."). As he notes, investment "sophistication" isn't an either/or test, and knowledge and education don't map cleanly onto outcomes: "Research evidence suggests that victims of investment scams are characterized by somewhat higher investment knowledge than nonvictims, a result attributable to the perils of ego and overconfidence. A little knowledge can be a dangerous thing." Id. at 126.

160. Such a proposal raises its own set of concerns, however. See, e.g., Christoph Busch, Implementing Personalized Law: Personalized Disclosures in Consumer Law and Data Privacy Law, 86 U. CHI. L. REV. 309, 310 (2019); Anthony J. Casey \& Anthony Niblett, A Framework for the New Personalization of Law, 86 U. CHI. L. REV. 333, 333 (2019); Omri Ben-Shahar \& Ariel Porat, Personalizing Mandatory Rules in Contract Law, 86 U. CHI. L. REV. 255, 255 (2019).

161. See, e.g., Epstein, supra note 153, at 811 ("[T] he neoclassical case for markets rests on the more qualified assumption that learning actually matters."); Zywicki, The Economics and Regulation, supra note 143 , at $1463-64$. 
other words, this model does not include consumers' own agency. After all, as the objection goes, consumers are "protected" from any activities that they won't "fall for," that they "protect themselves" from, whether by declining to enter into a particular transaction, or resisting certain forms or terms of a transaction. For example, they can decline the often-offered "extended warranties" and the many other upsell products that are not economically beneficial for consumers. It might be the case that technological advantages only hold sway, if at all, for a particular time and then fade in their power over savvy consumers.

This sort of adjustment is plausible, in many respects, as to consumers who are capable of making such adjustments - those in possession of a sufficient degree of technological or financial literacy. That said, there is reason for skepticism concerning the idea that "consumer education" obviates the need for external constraints on merchant behavior. ${ }^{162}$ In any case, assuming this learning sometimes occurs on a wide scale, the objection is that a model that ignores it could induce misguided policy efforts, which would further hinder efficient and beneficial commercial activities through onerous regulation. This line of thought is worth exploration, especially by empiricists who may be able to study the degrees to which theories of consumer behavior underlying this critique are borne out in reality.

This factor is omitted from this Article's model because this model is structured to deal with external constraints on behavior rather than selfconstraints consumers might provide for themselves, and there is no obvious way to integrate these "consumer adaptation" factors. If, indeed, consumers are capable of protecting themselves against a given merchant strategy, whether from the outset or through adjustment over time, then the justification for external protections of whatever sort will diminish. This model, in other words, is implicated when consumers as a whole or (more often) as a group with certain specified characteristics, are in need of the protection that can be provided by external sources such as regulations, institutions, technologies, or simply social opprobrium. Whether the need exists cannot be answered by reference to this model.

A more pointed version of the objection might be that this model is not as neutral as it purports to be regarding the underlying justifications for regulation. Perhaps the model "loads the dice" in a pro-intervention way by focusing on certain external constraints to the exclusion of other internal ones.

But this model leaves a wide opening for nonlegal, self-help mechanisms such as technological tools or public advocacy to be used as policy tools (as discussed in the preceding part). To extend the idea of self-help to the notion of a consumer simply thinking twice before engaging in a

162. See, e.g., Lauren E. Willis, Against Financial Literacy Education, 94 IowA L. REV. 197, 197 (2008); Van Loo, supra note 45, at 1349-50. 
transaction would move this Article from the realm of law and policy, and more directly to the realm of psychology. While other scholars are producing excellent work on the psychology of consumer commercial behavior, this Article is not intended as a contribution to that work. Insofar as these "interior" constraints are salient, they exist apart from and prior to anything in the model. This model focuses on factors that are more readily observable in policy analysis. It is not intended to denigrate or minimize the importance of underlying preferences, beliefs, and behaviors that are important aspects of consumer commercial relationships.

\section{Systemic Risk, Discrimination, Innovation, and Other Policy Con- cerns}

A final limitation is that by focusing on consumer protection, the model does not directly speak to other goals of consumer law and policy. These goals include working against prohibited forms of discrimination, fostering technological innovation, protecting trade secrets, and avoiding systemic risks to the broader economy that could be caused by consumer commercial relationships gone wrong. This model provides a framework for understanding what functionally constrains participants in transactions. It does not canvas all considerations relevant to normative judgments about particular policies or particular commercial transactions. Whether or not those policies are normatively desirable when the complete scope of their societal costs and benefits are considered is a question to which this model contributes but does not furnish the sole basis for answering. In other words, this model focuses on the constraints that regulate the commercial relationships formed between consumer and merchant. Because of this, it omits consideration of some of the externalities, whether positive or negative, of those relationships.

Subprime mortgage loans to consumers played a prominent role in the 2007-2009 financial crisis. ${ }^{163}$ The extent to which the primary cause of the financial crisis was consumer borrowing, rather than the esoteric financial uses to which it was put by structured finance experts at financial institutions, remains a matter of debate. Regardless, current regulations with respect to similar transactions are intended to protect the participants - and to cushion the broader economy from the shock of these loans all going bad at once. This model does not directly reflect the additional goals or effects of policies.

Similarly, this model also ignores the many technological changes that benefit society at large. For instance, technological advances often lower transaction costs in commercial relationships, benefitting all. Some innovations in FinTech companies have done this by facilitating payments in consumer transactions, permitting easier detection of fraud, and so

163. See, e.g., Van Loo, supra note 71, at 820-21 (summarizing scholarly sources and debates on consumer issues and the financial crisis). 
on. ${ }^{164}$ As mentioned above, some technological innovations lower costs by permitting companies to avoid regulatory compliance, exploiting regulatory loopholes, or evading regulators' detection of wrongdoing. ${ }^{165}$ These present and anticipated technological developments are relevant factors in determining whether to regulate and how to do so. Prohibitive commandand-control regulations may inhibit development of societally beneficial (and even consumer-protective) technologies. Fostering technological innovation is a social good, and innovation-dampening effects of regulation are externalities worth considering, but this model does not directly include such considerations.

Another example is antidiscrimination laws. These laws are intended to protect particular would-be participants in transactions, and the model therefore includes them in part. But they are also intended to contribute to broader societal goals, the inculcation and promulgation of important norms and values that go beyond a particular situation to some of our most cherished, fundamental values. The effect a given policy would have on discrimination norms more broadly (i.e., as affecting others outside of a particular consumer-merchant relationship) is not reflected in the model. ${ }^{166}$

Numerous other values and goals could be added to this list. Environmental and public health concerns are implicated in some consumer transactions. Consumer law disclosure regimes, which are intended to make sure corporate responsibility can be assigned for violations of law, can be used by competitors to threaten businesses' interests in maintaining trade secrets and other competitive aspects of their firm's activities.

These externalities are certainly relevant to the normative consideration of particular policies. Inclusion of these factors might lead to a variety of conclusions about regulation: one set of risks lies primarily in underregulation of systemically risky or discriminatory activities. Another set of risks lies in overregulation of (technologically enabled) commerce, and the innovation-dampening, anticompetitive effects of compulsory disclosure of trade secrets.

This Article is intended to support, and not preempt, efforts to include a broader range of factors in commercial policy analysis. While this Article's model focuses on consumer-merchant relations, a similar modeling effort might illuminate analogous interrelationships among different types of constraints in other relevant areas. Certainly, the challenges presented

164. See generally Bradley, supra note 3, at 63-80.

165. See supra note 141 and accompanying text.

166. It is also, of course, possible that certain policies might be most effective in accomplishing broader societal goals (for instance, those requiring public commitments and building "compliance culture" within firms). Others, by contrast, might have little effect on society at large but affect particular consumer relationships in a concrete way (for instance, policies that simply try to take certain forms of discrimination off the table, such as Airbnb's practical move to mask characteristics that hosts were using to profile potential guests, see Bradley, supra note 3, at $90 \mathrm{n} .102$ ). These distinctions, too, provide reasonable bases for policy discussions. 
by technological and social change raise significant policy concerns beyond those traditionally considered in the consumer protection literature.

\section{CONCLUSION}

This Article's consumer protection model provides a simplified, stylized depiction of complex realities. But it provides a flexible and comprehensive way of fitting together the many nuanced strands of empirical, theoretical, and doctrinal scholarship that have made consumer law a vibrant and growing area of attention (and controversy) in the United States and globally. This model depicts how different types of constraints on consumer commercial relationships work together, affect one another, and must be tracked carefully over time in order for accurate policy judgments to be formed.

The most important extension of this work will be in showing how not only the model, but consumer policy itself, could better incorporate distinctions among different types of consumers and merchants, different types of transactions and relationships, and among the various justifications thought to support different types of consumer protective laws and institutions. This model will hopefully aid in that future research and policymaking. 